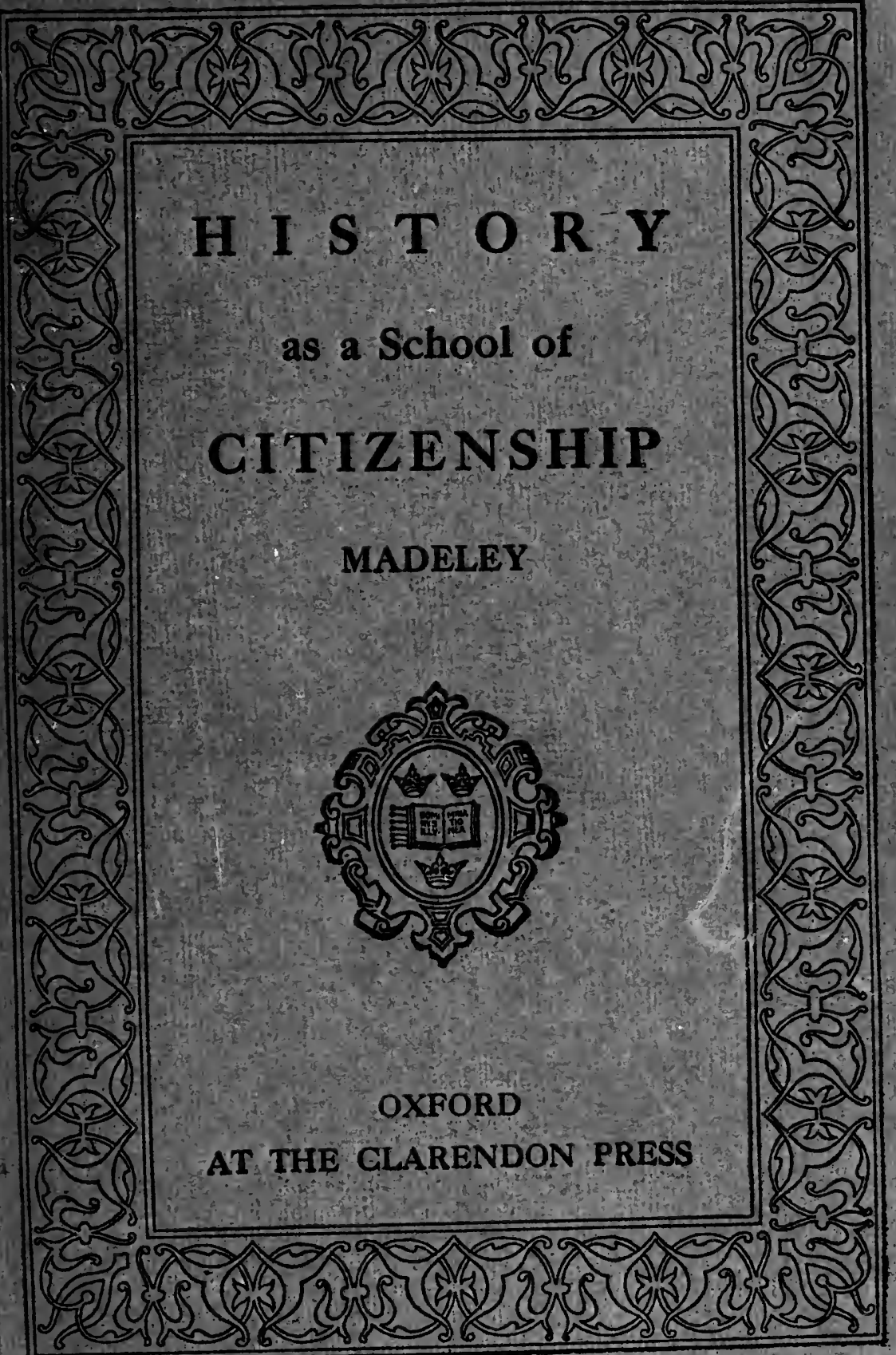







\section{HISTORY AS A}

\section{SCHOOL OF CITIZENSHIP}


PRINTED IN ENGLAND

AT THE OXFORD UNIVERSITY PRESS 


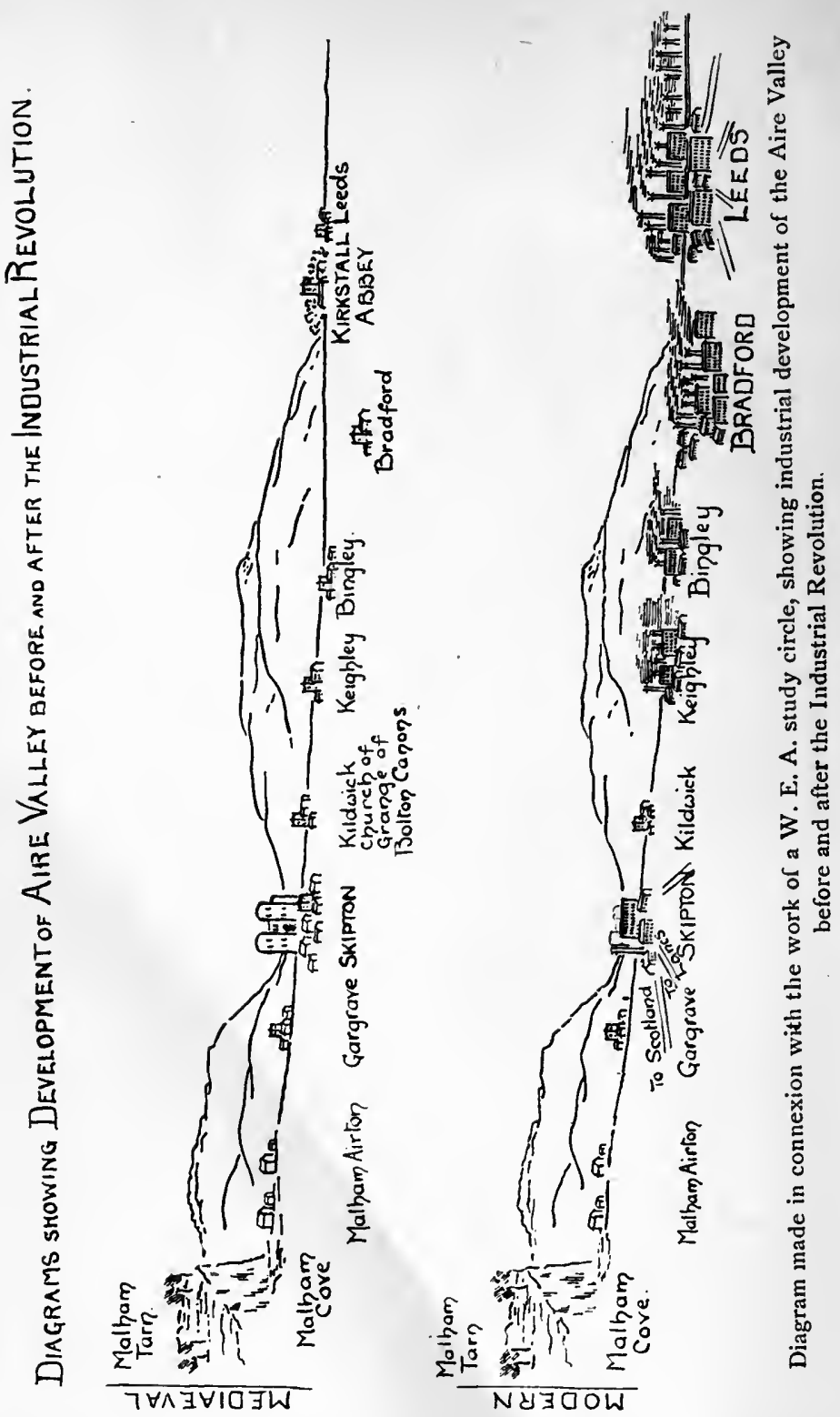


\section{SCHOOL OF CITIZENSHIP}

\section{BY}

\section{HELEN M. MADELEY}

SOMETIME ORGANIZING HISTORY MISTRESS, LEEDS GIRLS' HIGH SCHOOL

LECTURER IN HISTORY, BINGLEY TRAINING COLLEGE

WARDEN OF THE BIRMINGHAM WOMEN'S SETTLEMENT, AND DIRECTOR OF PRACTICAL. WORK TO THE SOCLAL STUDY COURSE OF BIRMINGHAM UNIVERSITY

WITH A FOREWORD BY

THE MASTER OF BALLIOL

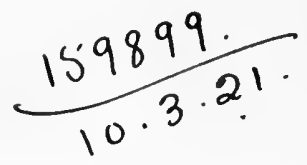

OXFORD UNIVERSITY PRESS

LONDON EDINBURGH GLASGOW NEW YORK

TORONTO MELBOURNE CAPE TOWN BOMBAY

HUMPHREY MILFORD

I 920 


\section{Digitized by the Internet Archive in 2007 with funding from Microsoft Corporation}




\section{F O R E W O R D}

THIs book is a striking proof of the amount of zeal and able thinking that is now being brought to bear on the practical problems of education. Teachers will find it full of suggestion, of stimulus, and of encouragement. A wider public will find it emin ently readable with its happy illustrations, its interesting experiences, and its vivid presentation both of principles and of methods. Education would not be regarded as a dry and dull subject if it were more treated with some of the humour and life, the insight and the many-sidedness, which Miss Madeley brings to bear on it in this little book on History as a School of Citizenship.

\section{A. L. SMITH.}

Balliol College, Oxford.

July 28, 1920. 

To

THE P U P I L S

WhO TAUGHT ME WHAT IS IN THIS BOOK

A N D THE COLLEAGUES

WHO URGED ME TO WRITE IT 


\section{NOTE}

A GOOD many people explore the possibilities of History teaching without any preliminary training. I hope that this little book may help them to place its chief problems, and to shorten the time during which they are finding their own solutions.

I have to thank the L. C. C. Shoreditch Technical Institute, Miss M. Barker, B.Sc., and my sometime colleagues, Mrs. Fraser Davies, Miss M. Morton, M.A., and Miss A. F. Purvis, for very generous loans of illustrative material.

H. M. M. 


\section{O N T E N T S}

\section{PART I. ENDS}

CHAP. PAGE

I. THE NEED FOR RECONSTRUCTION • • . 9

II. THE MAKING OF CITIZENSHIP . • • . II

III. CITIZENSHIP AND THE CURRICULUM . • • I7

\section{PART II. MEANS}

IV. RAW MATERIAL • . . . . . . $\quad 24$

V. ECONOMY . . . . . . . . . . 34

VI. TECHNIQUE .

VII. FIXTURES.$\quad \cdot \quad \cdot \quad \cdot \quad \cdot \quad \cdot \quad \cdot \quad \cdot 5^{2}$

VIII. ILLUSTRATION . . . . . . . . . $\quad . \quad 57$

IX. THE YOUNG IDEA . . . . . . . . . 66

X. BY-PRODUCTS . . . . . . . . . 73

\section{DETAILS OF PRACTICAL WORK}

History Syllabus used in Secondary School . . . . . $3^{\circ}$

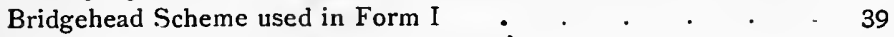

Bridgehead Scheme based on environment . . . . . 40

Details of Individual Lessons . . . . . . . . 76

(i) Revision Lesson on the Battle of Hastings, based on the .

Bayeux Tapestry. . . . . . . . 76

(ii) Introductory Lesson on the Religious Difficulties of the

Seventeenth Century, based on Costume . . . 79

(iii) Introductory Lesson on the Mediaeval Village, based on

a Domesday Entry . . . . . . $\quad$. 82

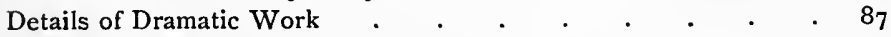

(i) Programme of Historical Variety Entertainment $\quad . \quad \cdot \quad 87$

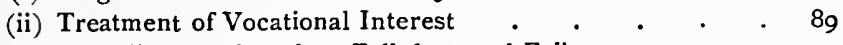

(a) Pageant based on Folk-lore and Folk-song.

(b) Masque based on Historical Allegory.

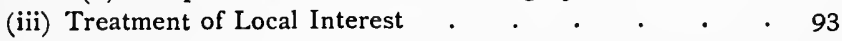

Fairy story used symbolically. 


\section{LIST OF ILLUSTRATIONS}

Diagram showing industrial development of the Aire Valley before and after the Industrial Revolution . . . . Frontespiece

Work done by girls studying dressmaking in a Trade School, showing use of history of costume as a basis for modern dress design (le 3 t by the L. C. C. Shoreditch Teclunical Institute).

Illustrations given by teacher in connexion with lessons on the History of English Costume . . . . .

Flat pattern made to measure of the sideless gown of the fourteenth century .

Design for tea-gown showing adaptation of the sideless gown for modern use . . . . . . . . 33

Time Chart for class-room wall . . . . . . . . $3^{8}$

Page from a book made by a child in a series of lessons on the Early History of Books (lent by Miss A. F. Purvis from work done at the Fielden Demonstration School, Manchester).

Hektographed slip for use in 'source lesson' showing method of abridgement

Part of a sheet made for a local survey, showing fourteenth-century tiles from the Priory Church, King's Langley (lent by Miss M. Barker from work done at The Priory, King's Langley)

Rolled Time Chart for field work (lent by Miss M. Barker) . . 54

Handwork based on the study of the Bayeux Tapestry (lent by Miss A. F. Purvis, from work done at the Fjelden Demonstration School) . . . . . . . . . . .

Diagram showing social and industrial developments at a milltown in the Aire Valley . . . . . . . . 64 Pages from a child's history scrap-book . . . . . . . . 68,69

Scene from a pageant based on four years local study. 'Preparing for a mammoth hunt' (lent by Miss M. Barker from work done at The Priory, King's Langley) . . . . . . $\quad 7^{2}$ Black-board sketch of Norman architecture . . . . $\quad$. 77 


\section{P A R T I}

\section{I}

\section{THE NEED FOR RECONSTRUCTION}

The leader of young opinion may create nothing but confusion and weakness... unless his power is related to some greater purpose in whose service is liberty.-Graham Wallas.

History teaching suffers from a too vague objective. It has its uses, but it compares badly as a utilitarian subject with Mathematics or Languages: it has its pleasures, but they can be attained more easily through Literature and Art. When we wish to maintain it, we are driven to remember that, like reading, it 'maketh a full man', and to defend it in terms of general culture.

But now that we are face to face with the real work of reconstruction, we are beginning to regard our time-tables more seriously and more thriftily. Already we are learn. ing to demand that the curriculum of the school shall be definitely and recognizably related to life as we mean it to be lived. We want its contents to contribute directly to efficiency, and to strengthen our hands as we build up our defences against another lapse into the chaos of cruelty and waste. And in this rigorous economy, subjects that claim their place on grounds of general culture and 'traditional information' will have to go.

Even short of this calamity, History suffers as a teaching subject from its indefiniteness of aim. We sometimes do not know what we may include, we frequently do not know what we dare exclude, because we are not sure of our purpose. And so we constantly leave by the way-side the most fruitful topics, and burden our lessons with the deadest of dead matter. We load our memories with the 
battles and genealogies of the Wars of the Roses, the ministries of George III, the terms of some defunct treaty or some long-repealed bill, and we leave untouched craft history which might give new life to our technical training, studies in social life which might bring a new sensitiveness into human relations, and political discussion which would give both a new zest and a new efficiency to citizenship.

For there are functions which History might make peculiarly its own, which are most proper to its material, and which no other subject can adequately fulfil.

The History teaching that aims specifically at the making of the citizen will need some re-orientation of subject-matter and some reconstruction of method, but it will gain an ease and precision of purpose and technique, which will more than compensate for the conventional knowledge, the vague picturesqueness, or the detailed exactitude which it loses. The History teacher who adopts the query, 'How will this help towards Citizenship?', as a test of fitness, will find very many pleasant things released, and very much tedious stuff abandoned, and will gain a definiteness of aim, and a certainty of touch, which no theory of general culture can give.

And the History teacher who achieves the civic orientation will share more certainly perhaps than any other member of the community in the work of reconstruction. 


\section{THE MAKING OF CITIZENSHIP}

I cannot praise a fugitive and cloistered virtue.--MiLton.

Three obstacles deter most of us from good citizenship :

We don't want the bother.

We have not all the virtues.

We don't know the ropes.

It is at the removal of these obstacles that our History teaching must aim.

In a certain number of people the impulse to public action comes simply from love of things well done, of efficiency and order, and from dislike of mess. The crusade against inefficiency belongs especially to the Boer War epoch : it is peculiarly a characteristic of Mr. Wells's young men. Most of us, however, need something more emotional for a prolonged effort.

Sometimes that something is found in pure altruism, in sympathy with individuals, and in the protective instincts they arouse. This is the commonest stimulus to civic action in the middle-aged $\vdots$ it is of all incentives the easiest to define; it is the one we all tend to revert to when jaded and disillusioned; so that it bulks large in books. ${ }^{1}$ But it is not the incentive that appeals most

1 Cf. Graham Wallas, The Great Society, 'If one asked a dozen of these modern leaders for an introspective account of the emotion of Public Spirit, most of them (if they were able accurately to observe their own consciousness) would, I believe, come back to that original Love and Pity for their fellow human beings as such', p. 153. 'Next to a high degree of original love, the most important of the factors by which our primitive Philanthropy becomes effective Public Spirit is an Imagination presenting to its possessor the existence of his fellow men with sufficient vividness', p. 156. 
readily to the young. In them probably the stimulus comes more often from feeling for the community than from feeling for the individuals who compose it. ${ }^{1}$ The exaltation which accompanies the recognition of themselves as an organic part of a greater whole seems to be a fundamental experience. Whatever its normal forms in the past, it seems in the present to be most readily evoked as patriotism, perhaps because as patriotism it is supplied at once with a local habitation and a name and a literature.

A good deal of patriotic feeling is little better than jingoism, the pride of domination, and the determination 'not to be beat'; but where it is waked young a more important factor is race consciousness, the impulse that becomes articulate in Ecclesiasticus, 'Let us now praise famous men and the fathers that begat us', and that looks back naturally

To the forgotten dead ...

To every fervent yet resolved heart

That brought its tameless passion and its tears...

To lay the deep foundation of our race.

The sense of the long past and of the link that binds us to it is implicit in much patriotic emotion, and exercises a strange and wavering fascination over the young imagination:
Very old are we men;
Our dreams are tales
Told in dim Eden
By Eve's nightingales;

and from among such dreams comes sometimes

The dream that fires man's heart to make,

To build-

even the New Jerusalem. ${ }^{2}$

1 Cf. the quotation from Schiller's 'Hymn of Joy' cited in The Great Society, p. 157.

2 The poems cited all appear in a co-operative anthology (Pcems of 
Some modern poetry suggests, however, that the most fundamental element in patriotic feeling is love of the land itself ${ }^{2}$ :

\section{God gave all men all earth to love, But since our hearts are small, Ordained for each one spot should prove Beloved over all,}

till the beloved spot becomes symbolic, and gathers to itself the sentiments and aspirations that are 'forever England '.'

But to many the most profound influence in calling out civic virtue is the perception of the sheer beauty of those excellencies of human character which find their largest field, their most distinctive opportunities, in public action.

To-day) ; so it may be inferred that they express the feelings of some of their readers as well as of their writers, and that it is not unfair to treat them as both evidence and illustration.

1 Rupert Brooke in the 1914 Sonnets is a good case. But recent poetry is so full of instances that it is difficult to select. When E. Hilton Young writes, in 'Christmas' ( $A$ Muse at Sea),

I should not mind to die for them,

My own dear downs, my comrades true,

But that great heart of Bethlehem,

He died for men he never knew.

And yet I think at Golgotha,

As Jesus' eyes were closed in death,

They saw with love most passionate

The village street at Nazareth,

he is being unusually direct and explicit ; but the sentiment he expresses is far from unusual.

2 The symbol is not always exclusively visual, though with many people it tends to be mainly so. And the beloved spot is not always the place of origin, though it often is. W. H. Hudson has a curious description, in $A$ Shepherd's Life (p. 29 in Methuen's cheap edition), of the charm possessed for him by a rather unattractive village on the Wiltshire Downs, a charm he could not account for till he realized that it was reminiscent, in its surroundings, of his early home. Most of us could parallel this from our own experience. 
Love of the heroic may sustain you in the workhouse or in the operating theatre; it will more certainly make you dauntless in the trenches, or even-far-fetched though it may seem-in the committee-room: and love of the heroic, therefore, tends to goad into some form of public service.

All good qualities help to make the good citizen; but courage, sympathy, and fair-mindedness are probably those one would select as peculiarly necessary to his equipment.

Courage in its epic form of gallantry one finds the most splendid. In its prosaic form of tenacity it is perhaps the most valuable-or at least that which is oftenest in default. The valour that will challenge danger is less rare than the courage that will face obloquy and social inconvenience; it is almost common compared with the endurance that does not flag before long-continued agitation.

In this as in other directions, probably the best safeguard of civic virtue is the power of sympathetic insight. We must develop an imagination so compelling that we cannot evade realization of the sentiency of every other human being if we are to be safe from the lethargy which perpetuates the social ills, and from the selfishness or the stupidity which originates them.

Such sympathy demands an intellectual effort almost as severe as fairmindedness-which in politics at least is mainly a question of sheer hard-thinking. We are not inured to endure hardness in things of the mind; in politics especially we love sentiment and cant phrases. We need a more realistic nomenclature. Even the party names puzzle and mislead some people, and the custom of describing as 'self-government' the prefect system of 
the ordinary school, or a political system which denied representation to more than half its subjects, encourages a habit of mind in which terms are divorced from reality and accurate thinking becomes almost impossible. We need to clear such expressions both of their vagueness and of their sentimental associations, and to use both them and our political arguments with more stolid common sense. And we need, still more obviously, greater power of weighing evidence and the even rarer capacity of listening to the other side.

All this involves willingness to think about political questions, and since that can only come if we think with ease, familiarity with their terms, and the habit of thinking in them, and readiness to transfer the experience gained in one department of life to another. If we used our knowledge of committees or our verdicts on social gossip in interpreting ministerial squabbles or estimating ministerial responsibility, our politics would be more realistic as well as more just.

But the problem is largely one of pure ignorance. Many people feel occasionally the impulse to public service, most show at times sympathy or common sense : but few people have the knowledge necessary to make their impulses and their qualities effectual. The schools have accepted some responsibility for teaching on the central government, but they are still very shy in tackling local machinery. Yet for most people it is only through local machinery that political action on any but very rare occasions, or at many removes, is possible. Popular indifference to local questions is often ascribed to their triviality. But no one who has shared the life of a scholastic community can believe that smallness of area necessarily 
diminishes interest, and triviality is positively attractive to some minds. The real obstacle to interest is not triviality, but tiresomeness; and that tiresomeness is mainly due to our bottomless ignorance of the machinery and the ritual.

The removal of that initial ignorance would be a service both to our public and to our personal life; it would make possible the widely diffused interest and widely distributed control which a democratic system needs, if it is to be kept healthy; and it would make public activities accessible once more to people of commonplace status and mediocre ability. We are political animals, and we are too many of us suffering from baulked disposition. If we were more familiar with the channels of public action, our aspirations for the ideal commonwealth, our sympathy with suffering, our indignation at abuses, might express themselves in public service instead of emerging in mere irritability.

Blake closed his famous battle-song with the quotation, 'Would that all the Lord's people were prophets'. One is tempted to take as one's motto now, 'Would that all the Lord's 'people were politicians'.

\section{Note.}

[It is easy to put one's finger on the practical needs; but it is not easy to think clearly about them, because it is difficult to get all the facts projected on to the same plane.

Looked at psychoiogically, the factors of civic equipment are of very different importance, or are important at very different levels; while incentive goes to the very roots of life, technical ignorance is as superficial as a blight or a cataract; though it inhibits the will as conclusively as the cataract prevents vision.

Viewed from the standpoint of practice as it concerns the History teacher, the three factors seem to me to be 
of equal importance: e.g. it is as disastrous for the teacher drawing up a History scheme to forget technical instruction as to forget incentive. While the technical information is of less value for the personal life, it is equally important for public action. And though motives and qualities are of slower growth, that growth once started by suggestion can proceed independently, while technical information is a matter of deliberate instruction; and the suggestion will probably come independently of the negligent History teacher, while the instruction almost certainly will not.

It is perhaps also worth while to remind ourselves that the inhibition of will, though it may originate in something very superficial, is not superficial in its effects, even on personal life.]

\section{CITIZENSHIP'AND THE CURRICULUM}

Who is The Happy Warrior? Who is he That every man in arms should wish to be? - It is the generous Spirit, who, when brought Among the tasks of real life, hath wrought Upon the plan that pleased his childish thought.

WORDSWORTH.

Probably for most of those who develop early, the first inspiration to public service comes from a perception of the beauty and romance of certain human qualities. 'I never heard the old song of Percy and of Douglas that I found not my heart moved more than with a trumpet', writes Sidney. Great literature constantly sounds this trumpe: call for heroic aspiration or achievement; the poetry of Blake, the thundering prose of Milton, Wordsworth's Happy Warrior, the Psalms and Prophets of the Old 
Testament-one or more of these would figure in most people's civic autobiography.

Generally it is the literature enshrining some famous deed that calls up this feeling; sometimes the action is fine enough to be quite independent of its literary dress. To many of us it is an intellectual feat to regard the Lay of Horatius as doggerel, so saturated have the words become with the emotion roused by high endeavour; and it is hardly possible to tell the stories of Joan of Arc, of Thermopylae, of Regulus, or of the stripling David, so clumsily that they do not awake an echo of enthusiasm.

One asks sometimes if one acquiesces too glibly in the assumption that children's ideals really help to form their characters. Are they more likely to acquire virtues because they admire them, or do they merely admire the virtues they already potentially possess? But even if the heroic story only rouses this latent quality, and renders it more constant and deliberate, it is doing much to make it actual and effective. And probably ideals of conduct do far more than canalize latent impulses; they do really determine the type of character that will be formed. Many children live very much in the stories that have touched their imagination. They act them in their own lives, sometimes inventing incidents, and living in a purely imaginary world, sometimes transmuting their real lives to match their fancies. ${ }^{1}$ We are apt to be repelled by this play-acting and fancy-feeling, because it is generally forced on our attention by the languishing, or pertness, which the girl

1 Catherine Morland in Northanger Abbey is the classic instance of this tendency; The Golden Age contains some slight but suggestive studies of it among younger children; it is treated from a rather different angle in Florence Converse's Children of Light.

The habit is probably less common than pure day-dreaming; it is certainly less generally recognized, but this may bc merely because it is more difficult to detect. 
shares with her pet heroine, or the sham recklessness which the boy copies from his favourite ruffian. No doubt such artificiality is wholly bad when the imagination is fed entirely on feeble and sentimental stuff. But in its less obvious romantic forms it seems to be closely analogous to physical play; in this day-dreaming children practise in sport the virtues they will need to exercise later in earnest.

The stories which grip a child's imagination probably influence him even more seriously in a less direct way. When a child gives himself to the contemplation of some character, his mind becomes alive not only to the virtues of his hero but to the circumstances which called them forth ; and inevitably he becomes sensitive to those features in his own environment which demand similar virtues from him; and through this sensitiveness to the demand for qualities, the qualities themselves develop.

The school curriculum should, therefore, contain much heroic and romantic material. Literature, History, and Scripture lessons must share the obligation of providing it ; but naturally much of this work will fall to the History teacher, and a wise scheme of History must take large account of the need.

The more pedestrian civic virtues find their nursery rather in corporate feeling than in heroic tradition. Most children first experience group feeling in games; büt it occurs also in connexion with various kinds of co-operative class-work and non-competitive play. With many boys and girls it probably first attains its heightened and emotionalized form when they join for the first time in the march-out of a large school. ${ }^{1}$ When corporate ritual is reinforced by prestige and tradition, the impression made may be a lifelong possession.

The exhilaration of belonging to a group, the satisfaction of subordinating oneself as a part to the whole, is intensified

1 Or in the singing of the school song or the school hymn. 
in organized games by competition and physical exercise, and linked up more or less closely to an etiquette of good form and endurance and fair play.

This is the word that year by year, While in her place the school is set, Every one of her sons must hear, And none that hears it dare forget.

'Play up! play up ! and play the game!' is a good maxim to incorporate; but if it is to serve for more humdrum-and more frequent-crises than the occasions when 'the Gatling's jammed and the Colonel dead', the half-automatic loyalty of school must be transferred to the greater and less picturesque community of adult life: and this transformation is not easy.

It is difficult to feel for the twentieth-century city, except in times of danger it is not easy to feel even for the twentieth-century state, the thrill of identification which the old well-defined and intimately realized group aroused. The modern community is too complex; we cannot easily see it as a whole. But it is less difficult if we have already the image of some simpler yet analogous group, so clearly defined and so well articulated that the vision of its communion is easy to attain; it is much less difficult if that community has historical affiliations with our own. Therefore a detailed study of early village or town life must be part of the History syllabus. If it is the local village or town, so much the better. Whatever fixes attention on the neighbourhood serves here; for it ought to be loved, and to be loved it must be looked at. The regional trend of geographical and scientific teaching contributes to this end; and for the many to whom love of the Motherland develops from love of their own country-side, such local studies are equally essential to the larger patriotism.

The ethics, as well as the emotions, of school need transmuting to civic purpose. The 'school-boy morality' of the 
playing-field must be intellectualized if it is to guide our adult life, reinterpreted and reapplied if it is to purge our politics. For this, informal discussion supplies the best method, the concrete instances of History the best material. Red herrings are popular in most class-rooms; even the shyest pupil will share in a discussion rather than let the teacher return to (what he supposes to be) the proper, subject of the lesson.

Discussion generally arises without conscious effort on the teacher's part : but it is well deliberately to include in one's scheme of work an intensive study of some disputed questions of conduct and fact. The material of the historian is nearer to the complex stuff of life than that of the scientist and the mathematician: and such an effort at analysis and criticism should make it easier to transliterate into conduct the standards of precision in statement, candour in argument, and open-mindedness in observation, which Science and Mathematics characteristically cultivate. We have all been instructed in the fallacies of formal training: but if habits cannot be transferred from one department of life to another, at least ideals can.

It seems to be along such lines as these that we must cultivate fair-mindedness and justic̀e. For the development of sympathy we should naturally look mainly to literature, and to literature rather as a leisure occupation than as a technical study. But the capacity to put oneself in another person's place is helped by all good teaching-by anything, in fact, that tends to make new material 'come alive' in the mind ; and History offers a special contribution, for one of its functions is to secure the imaginative reconstruction of different surroundings and conditions, and such exercise of constructive imagination must make easier the understanding of other lives and their circumstances.

If sympathy and fair-mindedness are to be politically operative some of our teaching must be deliberately pro- 
phylactic. There are still many vulgar errors to dissolve -beliefs in superiorities of race engendered in old-fashioned anthropology, beliefs in 'natural enmities' based on too much garish history, insular prejudices and myopic views resulting from too dittle history of any kind. Such prophylactics must usually be administered in the History lesson, though other subjects will have to do their share.'

Examination categories generally ensure that teaching on the mechanism of the central government should form part of the History course : but local government, where it is tackled at all, is frequently put into a compartment by itself, and labelled 'Civics'. This curious practice apparently results from the fact that the subject is uninviting; so that it is only by committing himself in advance on the time-table that even the conscientious teacher can guarantee against its complete neglect. Yet it is the last subject that can afford a separate pigeon-hole: it cannot be treated without self-consciousness where its purpose is made so very explicit, and its subject-matter is peculiarly unsuitable for administration in large doses. Owing to the complexities and inconsistencies of our local machinery, it is tedious to teach it systematically, impossible to teach it philosophically. Its only chance is an incidental introduction in some other lesson; and since the material has historic affiliations, the History lesson is the obvious place.

But the most important civic work of the school belongs neither to the class-room nor to the playing-fields. The political experience which a boy or girl can gain in the selfgoverning activities of so closely observed, and so intensely

1 The first difficulty instanced is for many people more easily dissolved by Literature or Art than by History. Cf. Graham Wallas, The Great Society, p. 158 : 'It is largely due to Sir Walter Scott that Englishmen can love Scotchmen more easily than they can, for instance, love Irishmen'. In this connexion the correlation between the status of Japan in public opinion and the appreciation of Japanese art is interesting. 
realized, a community may be made more vital and more suggestive than anything after-life is likely to offer. Even the Games Committee and the Prefects' Meeting are well worth while; and teachers who have taken the trouble and risk of carrying through experiments in genuine selfgovernment have come upon quite valuable results.

'Although the political side of the self-governing experience (the speeches, elections, and parliamentary busi. ness generally) interested the boys at first, it gradually fell out of favour .... the boys got over their party politics as a puppy gets over his distemper, for the simple reason that the whole body was working to achieve a healthy system.' ${ }^{1}$ ... 'Most of them detest collectively inflicting punishment, and they do not withdraw their admiration from the law. breaker when he deserves it., ${ }^{2}$ Observed facts of this kind are suggestive to the boys, as well as to their master. Personal experience of constitutional expedients, working on a small enough scale to be vividly realized, should make the best ground-work for sound political thinking and healthy political action later on.

1 H. Caldwell Cook, The Play Way, p. 60.

2 J. H. Simpson, An Adventure in Education, p. 55.

These books owe much of the value of their treatment of self-government to the fact that they carefully delimit the sphere of experiment and recount failures in more detail than successes. 


\section{P A R T I I}

\section{RAW MATERIAL}

England expects-I forbear to proceed :

'Tis a maxim tremendous, but trite:

And you'd best be unpacking the things that you need

To rig yourself out for the fight.-LEwis Carroll.

THE first business of the History teacher is the selection of subject-matter. That must vary to some extent from school to school. Political material which would be deadly to the children of the agricultural labourer or of the small shopkeeper, may be valuable and vitally interesting, to boys and girls whose fathers and fathers' friends are half of them M.P.'s. Topics which are already connected with the interests of the class can safely and usefully be taught in detail. But, on the other hand, matters of fundamental importance must not be left permanently out of the range of their sympathies; agricultural development will be more readily intelligible and interesting to the farmer's sons, than to the politician's, but it is more necessary to spend time making the life of the country-side a reality to the latter than to the former. So that a list of the subjects that cannot be left out would probably be largely the same for most schools.

Good heroic material is for the most part military; the Persian Wars, the Second Punic War, the Hundred Years' War, and the risings of Wallace and Bruce are the best specimens. They provide an easily grasped motive, picturesque characters, much fine and romantic incident. Morally, too, they are satisfactory stuff, for they show success on the side that fights against the big battalions, and stress endurance as much as daring. The Punic War 
presents a useful paradox, for children, who always take sides, can never arrange their sympathies between Hannibal and the Republic. In the Scottish and French Wars Wallace, Bruce, and Joan of Arc become so much the most 'sympathetic' characters that children under twelve are usually swept off their feet, and acquiesce quite cheerfully in the fact that their favourite heroes are among their enemies-a good antidote to 'militarist' infection.

The best safeguard against militarism is a more careful teaching of Military History, not an avoidance of it. 'Militarist' feeling is much more closely linked to the impulse of personal aggrandizement than to the instinct for corporate action, and the mere fact that a battle is realized as a co-operative achievement, not as a series of single combats, is a prophylactic. Naval History supplies good subjects, because here the combatants are crews, not individuals ; and in the case of Nelson's campaigns, where strategy can be utilized as well as tactics, this point becomes emphatic.

Good teaching will often bring out the wastefulness of war as vividly as its heroism; where the motives and results of, e. g. the Scottish and French Wars, are studied, children are not slow to see its. futility from the point of view of the aggressor. This futility is seen even more clearly where the development of military science is-deliberately followed up. As one studies the history of mediaeval armour, and watches plate strengthening plate till the man disappears within his accoutrements, and he becomes simultaneously invulnerable and immovable - very unlikely to be wounded by his enemies, but exceedingly likely to be smothered in his own defences-one can hardly avoid conviction of the sterility of militarism.

Religious History also seems at first sight a dangerous subject, but it cannot be omitted without leaving certain modern movements unintelligible; and many of its leaders 
are valuable subjects, not only as heroic example, but also because they induce tolerance, for they compel realization of the fact that heroism is compatible with a point of view with which we can no longer sympathize. The special difficulties which religious history presents can best be overcome by emphasizing the positive, rather than the negative, aspects of religious movements. In dealing with pioneers whose work was mainly constructive-e.g. the monastic leaders, St. Francis, or Wesley, the problem is comparatively simple, if enough care is taken to make real the social milieu in which that work was done. But where a movement was largely destructive, it needs a good deal of skill to get emphasis on the leader as a human being, and to illuminate the positive rather than the negative side of his aim and achievement.

Detail of religious controversy should never be dwelt on. Immature minds cannot really grasp the points at issue, and attempts to formulate and define fundamentals which are not understood are both wasteful and injurious. They lead occasionally to much personal distress, and often to a permanently narrowed outlook on sectarian differences.

Political History is apt to be dead matter to people under I5, unless it has topical interest, or is enlivened by rowdyism ${ }^{1}$ or mordant personalities. Thumb-nail sketches of the leaders often give the necessary fillip, but it is a sound rule to leave it as far as possible for later study, and to concentrate on more congenial material.

It is generally assumed that this is biographical, mainly on the strength of Plutarch's popularity. But in reality young children are interested in personalities, rather than in persons: and the success of the biographical method is probably largely due to the fact that teachers using it generally introduce plenty of anecdotes, more especially

1 e.g. The holding down of the Speaker in 1629 is a scene universally popular. 
anecdotes of childhood. Anything about children appeals strongly up to the age of 12 or 13.

Social and Economic History is specially valuable; it illuminates so many things that are familiar, and vitalizes so much that is generally ignored: it helps to develop social feeling, and compels imagination. Pre-historic material has these virtues in a very high degree; and it adds to them another: for it interests children early in questions of anthropology, and so teaches them to regard the remote and backward races with curiosity and respect as the depositories of an older culture, instead of with contempt as mere losers in the struggle.

The intensive study of a social group is so important for the waking of communal consciousness that it ought not to be confined to Pre-historic work. All early history abounds in good and not-too-complex subjects. Pastoral life is very happy material, because the children's familiarity with the Old Testament stories enables them to provide illustrations and parallel instances; Rome and the City States of Greece are strong in interest on the political side: best of all, perhaps, are our own mediaeval towns and villages, especially where these can be approached through a local example and the group interest and the local interest can be combined. Local feeling is extravagantly strong in children, and should be ruthlessly exploited by the History teacher.

Among local studies, architecture is one of the most valuable. Children are always excited to hear of a local antiquity, and military and ecclesiastical buildings furnish such clear instances of development that mediaeval remains are unusually good subjects. But domestic architecture, especially of the humbler sort, though less obvious, is equally fruitful, and for adults even more interesting. One becomes quick to note the characteristics of the local style, and to trace their origin in necessity or use, and one's 
pupils are never tired of discovering fresh examples, and finding ingenious explanations. This applies both to the general plan and to the details of domestic architecture; and a better understanding of its historical causes may lead not only to a new interest in places, but also to a readier sympathy with their inhabitants.'

Social and economic change is a difficult study for children under I4, but peculiarly fascinating from $\mathbf{I}_{5}$ onwards. This is markedly true of the causes leading up to the French Revolution, and to the Industrial and Agricultural changes of the eighteenth century; and these form a good jumping-off place for economic theory.

Backward and 'difficult' forms are at the outset most easily interested in externals, and these are, for them, probably the safest introduction to more intellectual matter. Costume work is peculiarly valuable as a clue to social atmosphere; it fixes attention; it gives 'something to do'; and it leaves children a chance of making observations, inductions, and generalizations, for themselves. In the study of a difficult and dry subject, such as the struggle of Cavaliers and Roundheads, costume is probably for most forms the best opening move.

Constitutional History must rely very largely on topical allusion; a contemporary Cabinet crisis, a neighbouring by-election, will produce the queries necessary for a good send-off, and a clear objective; but a broad and simplified treatment is equally essential, for interest is more important than information. And next to interest in importance is critical common sense. We have not yet got Burke out of our blood; and we are so acclimatized to the British

1 Dorothy Canfield gives a good instance of this in her account of the young Americans' comments on French customs in house-building (Home Fires in France, p. 12). Girls already in industry seem to be most readily interested in pictorial art, especially where they can trace a development. 
Constitution, that we are apt to forget that primogeniture is not a law of nature, or representative machinery an inevitable growth. Some idea of the stages by which representation became the key-note of our constitution, some knowledge of the devices by which Athenian democracy avoided the ballot-box, may be made very clarifying to the mind.

It is perhaps even more important that the boys' and girls' own experience should be brought within range of the History lesson. The work gains enormously in vividness and point where school machinery can be frankly discussed, especially where the machinery involves some self-government.' Constitutional History that is articulated to the newspaper at one end, and to the school committees at the other, can hardly fail to be both interesting and realistic. $^{1}$

Almost any topic can be made attractive by sufficiently skilful teaching; and some information is so important on utilitarian grounds that, even if the necessary interest can only be secured by a tour de force, it must be included. But the amount of effort needed in presentation is some index of the suitability of the subject-matter. Congenial material 'goes' well; and the 'food value' of the material can to some extent be gauged by its congeniality. A healthy mind, like a healthy body, has the best appetite for the food that is good for it. If one's pupils don't take kindly to the history one offers them, there is a prima facie case for examining its use; and, unless that is very obvious, for

1 Any government machinery is good material for such discussion if it is candidly named and worked. A system that is frankly and wisely autocratic may be very valuable to the teacher. And self-government itself, if it is to be educative, must be genuine as far as it goes. Doctored by authority it is (as political experience) merely vicious. Self-governors should either rescind, or suffer under, ill-advised or ill-drafted legislation. 
changing the subject. History offers so many subjects that this can easily be done.

\section{History Syllabus. Girls' Secondary School.}

The chief disadvantage of this school was that new girls entered in considerable numbers in every class: so that much repetition (on the time-table) was necessary to prevent large gaps in their equipment. Among its many advantages was a very strong classical staff.

This syllabus was tested by several years' use. Its worst defect was that under it recent history was apt to be treated too sketchily. The chief modification found necessary was that when the classical mistresses took Ancient History its scope had to be confined to Greek and Roman. Form I.

Pre-historic work.

Stories from General History.

Form Lower II.

Stories from English and European History.

*Form Upper II.

English History to 1066.

Stories from Ancient History (Oriental, Greek, and Roman).

*Forms Lower III, Upper III.

English History, 1066-1689

Stories from French History $\}$ two years.

*Forms Lower IV, Upper IV.

English History from r689 including Colonial History. $\left.\begin{array}{l}\text { Outlines of Ancient History (Pre- } \\ \text { historic, Oriental, Greek, Roman). }\end{array}\right\}$ two years.

${ }^{*}$ Form Lower V.

English Constitutional History.

European History (Mediaeval). 
*Form Upper V.

English Industrial History and some beginnings of Political Economy.

European History (Modern).

FORM VI.

Intensive study of periods for examinations.

* In these forms one lesson each week was given to English, and one to Foreign, History.

Work done by Girls studying Dressmaking in a Trade School, showing use of History of Costume as a basis for modern dress design.

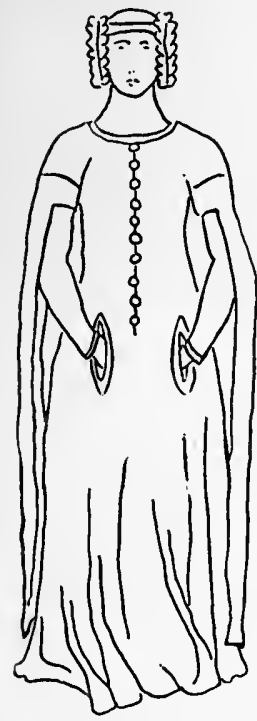

Cole Hardie

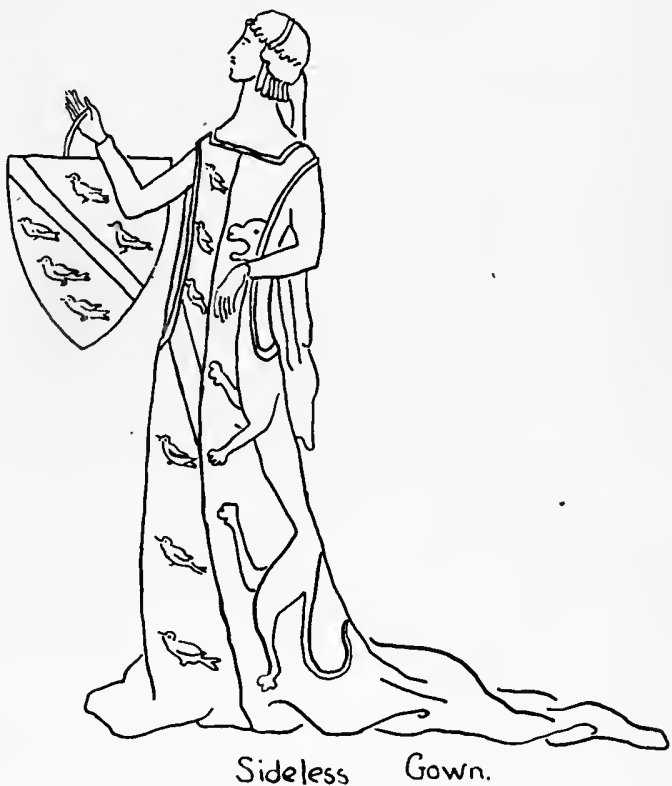

Sideless Gown.

Illustrations given by teacher in connexion with lessons on the

history of English costume.

The outlines were cyclostyled by the teacher and filled in and coloured by the pupils. 
A-B. heck to waist +3 .

B-C. 7 . for hep line.

A0. Shoulder to floor

A-E. heck to want frack - I"

E-F. $y^{*}$ for hiep line

AG Shoulder to flone.

G.H. 3 of $A$ i

AI. IS of neck measele..

A-J. 1/2 of neck lo waist front - 14

$J \cdot K \cdot 1 / 4$ of chest measure

K.L. $J \cdot K+\frac{5}{6}$

IH. $1 / 2$ of $A I+\cdots$. Cowered. 4.

ON- $1 / 3$ of $1 / 2$ waest $+1 / 4$

co $1 / 2$ of $1 / 2$ hifw +1 "

op. Full evaist + "

A Q $1 / 2$ of $A J-Z^{*}$

QR $1 / 2$ of $1 / 2$ widte back - $1 / 2$ "

Is. IM lowered $1 / 2$ "

ET. 3 of $1 / 2$ wowl measure

$F u \mid 1 / 2$ of $1 / 2$ hipo

G* 'Full renciat-I"

$H W G \cdot V$

$w \cdot x \cdot G+i l s \cdot \sin$.

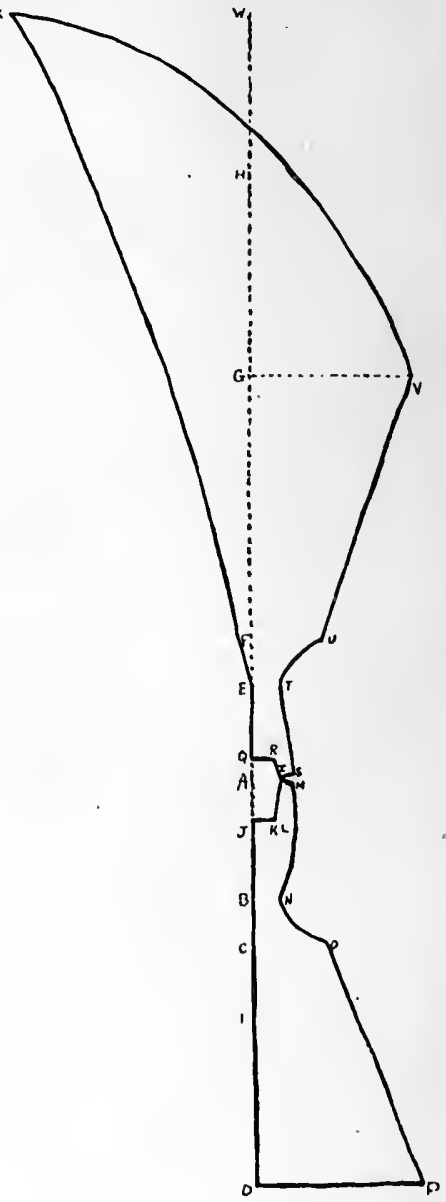

Sheet from girl's portfolio showing flat pattern made to measure of the sideless gown of the fourteenth century.

The measurements were dictated by the teacher; the draft pattern was constructed from them by the girls (age I4-15). 

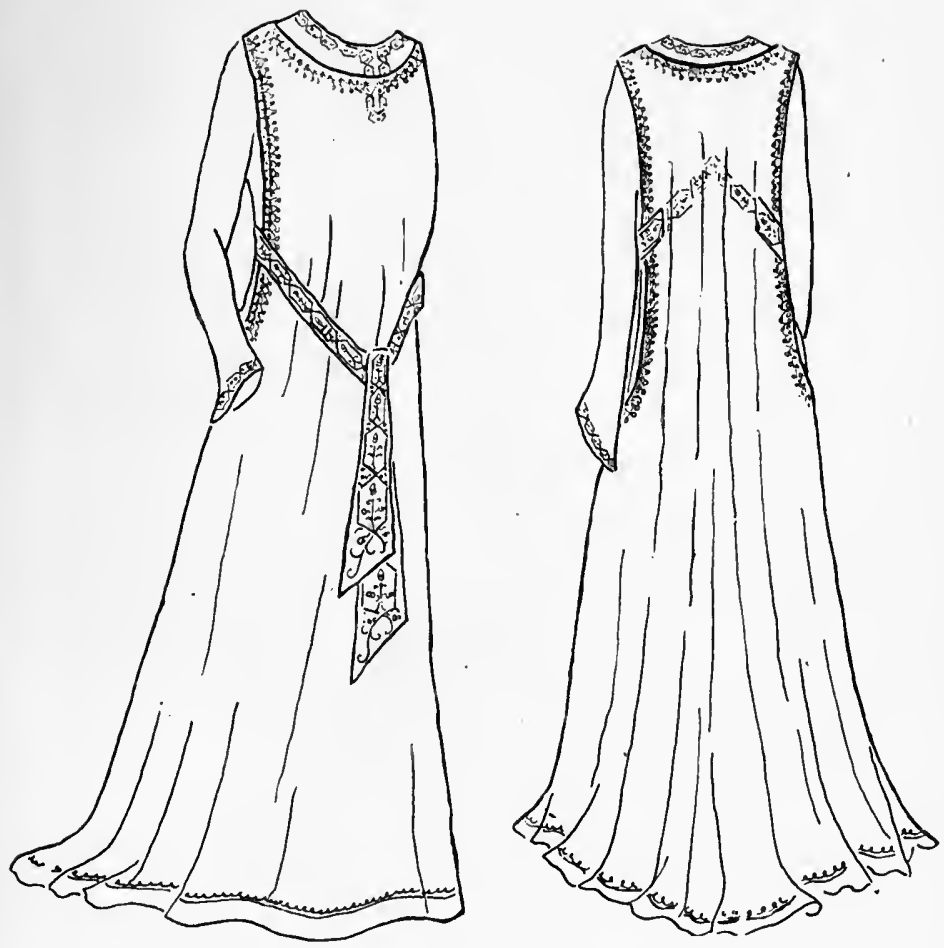

Design for tea-gown showing adaptation of the sideless gown for modern use.

The design was made by the girls and the tea-gown was made and embroidered by them from this design.

[Lent by L. C. C. Shoreditch Technical Institute.] 


\section{V \\ ECONOMY}

Water Baby. 'I hear you are very busy.'

Mother Carey (without stirring a finger). 'I am never more busy than I am now.'

Water Baby. 'I heard, ma'am, that you were always making new beasts out of old.'

Mother Carey. 'So people fancy. But I am not going to trouble myself to make things, my little dear. I sit here and make them make themselves.'-KingSLEY.

THE teacher's difficulty is not to find enough good material for civic studies, but to get it all in. This involves the practice of a most rigid economy; and for this there are three golden rules.

(I) Seize the Psychological Moment. Children are wonderfully intelligent and can digest almost anything; but none the less it is a pity to give them unsuitable food. It wastes time in a double sense; they do with difficulty at Io what they might do with ease at 16 : they cannot do at I6 what they might have done at Io. A skilful teacher can make the beginnings of the jury system interesting to the Lower Second; but six years later it could have been done with less time and less skill; and six years later work that might have been done in the Lower Second cannot be done at all; for at 16 people are critical and reserved and the time for indulging in enthusiasm is for many of them over.

The psychological sequence is fairly clear. Up to 9 or Io the centre of interest is the story; they love anecdote, legend, and romance. Especially they love the romance of 
strange surroundings, and for children just out of the Kindergarten the reconstruction of some different social life is the surest bait.

Children of 7 are sometimes too dull and backward for connected stories, but the Cave-men succeed where even Achilles fails. ${ }^{1}$ Quite apart from its certainty of appeal, pre-historic work is a sound basis. The most serious difficulty of the History teacher is to ensure that the class is not merely 'sitting still and being treated ', that a real imaginative reconstruction is going on. Pre-historic teaching forms a good habit at the outset. The conditions are so different from our own that some intellectual effort is inevitable, and so simple that even with a dull child that effort is likely to be successful. And it is of all history the easiest to learn, and to test, 'by doing'; so that the misconceptions into which children fall when words are the chief medium, can easily be detected.

Very soon-at about 8-a new taste appears. The magic of 'old, unhappy, far-off things' begins to.tell, and for many children the mystery of extreme antiquity becomes a compelling enchantment. The fascination of awe is strong for all imaginative children. Even for the prosaic, the joys of hero-worship become an experience. Between 8 and ro is the best time to kindle enthusiasms and to cultivate the love for the heroic: and this is the place to get the best heroic material into one's History scheme.

Between Io and I2 feeling veers. Most people become critical. At 8 they hardly ask 'Is it true?' Somewhere round 9 they are eager to sort the probable and the

I It is generally assumed by writers of pre-historic books for children that interest cannot be aroused unless the story centres in some imaginary character. But my own experience is that little children become quite as keen about the development of the habitation as about the adventures of young Sharpeyes or little Tig.

${ }^{2}$ Libellous description of my history lessons given me by a boy of 7 .

C 2 
impossible, in stories of Arthur or even of Alfred; and soon after Io, they want to know what is the use of History, and what it has to do with them. ${ }^{1}$

Many forms are happiest with work that unravels the world as they know it-History that explains nomenclature, or relics, or usages. But a difficult form will sometimes need a complete change of approach every halt term: for, with this phase, comes a restlessness that demands variety and novelty, and as much action as possible, pugnacious action preferred. Many children during this period react to a determined utilitarianism, and all their history must be explicitly purposive. With a form at this stage, utility is a safe card to play; the most notorious Fourth Form I ever handled became serene and studious when they heard that the Head Mistress needed a collection of battle-models, and that a gift of specimens towards the end of term would be welcomed and used.

After 14 the class-room becomes more peaceful. Boys and girls are interested in anything that shows development ; they want to generalize for themselves, and industrial history or constitutional history, which can be used as a starting-place for generalization, is sure of a warm reception. Many boys and girls begin about this time to feel, like Maggie Tulliver, the need for 'a secret of life that will enable them to renounce all other secrets'; and as their minds push out towards a philosophy, they welcome any theorizing which seems to carry them a stage further on the way.

By 16 the historically-minded are ready to take a scholarly interest, and make a detailed study of a period,

1 The coming of the Age of Prose is alluded to (from the stand-point of the still romantic junior) in Kenneth Graham's Golden Age, but its inevitability is camouflaged a little by the fact that in Edward's case it synchronizes witl the first term at school. 
and after this age, in the secondary school, more bookish and academic miethods can safely be applied.

2. Secure the Bridge-heads. The possibility of effectual intensive work in the later stages will depend very largely on their history in the past. The History teacher must be perpetually seizing bridge-heads on the unknown; and the awkward age, when monotony is intolerable and concentration not to be obtained, can be utilized to create a whole series of such bases, from which advance will be possible and easy later on.

The reluctance with which the duller-witted read can be dissipated quite amazingly by an early acquaintance with allusions; the ease with which the abler boys and girls absorb information depends largely on their previous familiarity with a name or a date to which it can adhere. The child who has heard and charted the tale of Caesar and the Standard-Bearer, is fairly safeguarded against the hopeless-and not uncommon!-confusion between Normans and Romans; the story of Bucephalus is not very educative in itself, but it is worth a good deai to have Alexander as a fixed and friendly figure for future use.

Bridge-head teaching shares the danger of all concentric methods : it risks staling the story. But the risk is a slight one if the second recension deepens the humanity of the central figure, develops the study of social conditions, or reviews the episode from a different angle in the mirror of a contemporary document.

It is well, however, to remember this danger in using a bridge-head scheme, to keep one's eye on the future, and not to exhaust material one must use again later on. Nelson is a better bridge-head for the Napoleonic Wars than Waterloo, because (among other reasons) he supplies endless anecdote, while ' $U p$, Guards, and at them', when once familiar, leaves little to relieve the tactical study of the Battle. 
3. Eschew the Link Lesson. A bridge-head scheme involves this; it may involve the abandonment of chronological sequence altogether. But there are few dangers in this which are not met by the lavish and consistent use of charts.

The ideal solution is a wall-chart running all along one side of a class-room, and two or three feet deep, so that pictures of all sorts can be stuck on it. Made of brown paper, with its time-line and centuries marked in Chinese white, or of white paper with divisions in black and red, it becomes quite a decorative object. It supplies an excel-

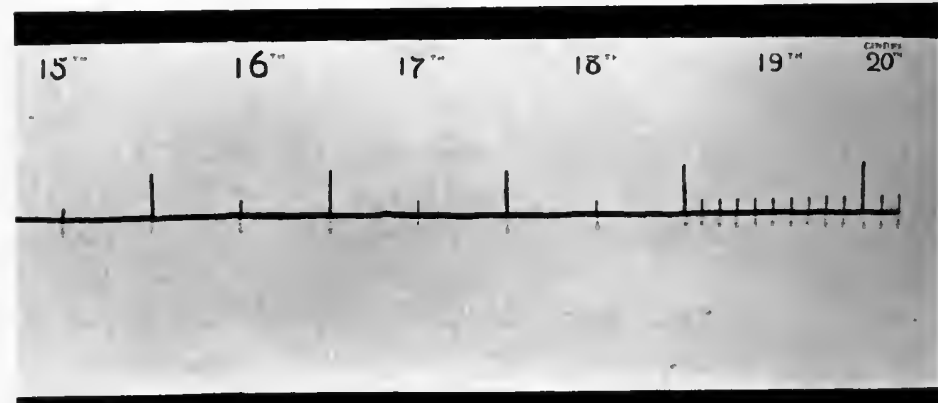

Wall chart ready for use. The chart from which this section was taken was made of lining paper 20 inches wide at $\mathbf{x}_{2}^{1} d$. per sheet.

The advantage of this type of chart is that it serves for the exhibition of pictures as well as for the fixing of dates and the comparison of time distances. If it is carried past the B. C. line its use also does away with the common difficulty over the naming of the centuries.

lent motive for the collection of pictures and the making of drawings; it fixes the sequence of events almost without trouble; and it minimizes, while it is in use, the need for the link lesson, and so enables one to jettison a great deal of dead matter. ${ }^{1}$

1 A chart of the kind described has a further advantage. Where a 
Bridge-head Scheme used in Form I of a Yorkshire secondary school ; Boys and Girls, average age, 8.

Pre-historic man : development of his methods of providing food and shelter.

The Pyramids.

The Story of Abraham.

Hector and Achilles.

The Childhood of Cyrus.

The Spartans.

Stories of the Persian Wars.

Alexander and Bucephalus.

Romulus.

Horatius.

Hannibal and the Romans.

Caesar and the Standard-bearer.

Constantine the Great.

King Arthur.

Gregory the Great and the children.

Caedmon.

The Danes and Alfred.

Cnut.

Harold and William.

Richard I and the Crusades.

St. Francis.

Stories of Giotto.

Dante and Beatrice.

St. Louis.

The First English Prince of Wales.

Tales of the Scottish Wars: Wallace, Douglas, Bruce.

The Black Prince.

Joan of Arc.

The Printing-press.

child is suffering from too much sedentary work, it supplies the teacher with a handy reason for giving him or her some exercise. 
Columbus.

Drake's Voyages.

The Armada.

Peter the Great.
General Wolfe.

Washington.

Nelson and Napoleon.

Florence Nightingale.

Bridge-head Scheme for English History, showing the initiation of each piece of work by the observation of some connected feature in the pupil's own surroundings. This scheme was drawn up for a class of girls (aged about Io) in Leeds.

Pre-Teutonic peoples. ${ }^{1}$

Roman occupation.

The English Settlement.

English Mythology.

The Conversion of the North.

St. Patrick and the Irish Saints.

The Danish Invasions.'

The Norman Conquest.

Early modes of trial. Monasticism.

Crusades.

Hundred Years' War.
Mistletoe custom or Swastika.

'Street Lane.'

'The Oak.'-'Shire Oak Road.'

'Tuesday', 'Wednesday', $\& c$.

Church dedications, e.g. St. Hilda's, S. Cuthbert's, St. Aidan's.

The Shamrock (badge of one of the School 'houses'). Place names ending in -by. Words introduced by Normans, 'beef', 'mutton', \&c.

'Getting into hot water.' Kirkstall Abbey. St. George's Cross. Black Prince's Statue, or Prince of Wales's crest and motto.

1 Most forms in a Leeds school could also approach these subjects by observation of the physical characteristics of their members-Nordic and Mediterranean types being strongly marked in this district. 
Mediaeval Trade.

Quarrels of York and Lancaster.

Renaissance.

Geographical discoveries.

Reformation.

Drake, Blake, Nelson.

The Stuarts and the Quarrel with Parliament.

Cromwell and Charles II. Revolution of $\mathbf{1 6 8 9 .}$

Anne.

Unions with Scotland and Ireland.

Stuarts and Hanoverians.

American War of Independence.

French Revolution.

Modern Scientific development.

Industrial Revolution.

Indian Empire.

Colonial Development.

Central Government.
Fleece in the Leeds coat of arms.

White Rose of York (emblazoned on window of school hall).

Printers' Type.

Potatoes: tobacco.

'Fid: Def:' on coins.

'Admirals All' (quoted in most school anthologies).

St. John's Church (Laudian) and its memorial window.

Royal Oak Day.

'God save the King.'

'Queen Anne's dead.' .

Union Jack.

'Wi' a hundred fighters an' a', an' a' ' (song of one of the school houses).

Stars and Stripes.

Tricolour.

Statue of Priestley in City Square.

The Mills.

'Ind : Imp :' (on coins).

Red patches on the map,

or Colonial uniforms.

Post Office and its work.

[It is, of course, important that the subjects should not be approached in chronological order. Chronology should be dealt with by the use of a wall-chart.] 


\section{VI \\ TECHNIQUE}

Opinion ... is but knowledge in the making.-MrLton.

The methods by which historical knowledge can be induced fall into five classes:

(I) Narrative.

(2) Experiment.

(3) Discussion.

(4) Source Work.

(5) Individual Exploration.

(I) Story-telling is the first art of the History teacher; it is the chief method for teaching little children; it remains an indispensable accomplishment to the teacher of older boys and girls; and to the teacher of the tired adult it offers always the easiest and often the only mode of approach.

After I4 the terse anecdote becomes effective; but younger boys and girls like their stories developed and detailed for them. For quite little children much vamping is needed, and every process and reflexion must be made explicit. People under ro have not reached the stage of boredom which discovers the connexion between brevity and wit. ${ }^{1}$

Consequently narrative, especially narrative for young

1 This is true also of adults whose academic education has been left far behind and on whom the pressure of life has been peculiarly heavy. They need much the same kind of narrative treatment as young children, though, of course, they appreciate very different subjects. 
children, needs careful rehearsal. Phrases are misunderstood, a climax is not appreciated because the steps leading up to it have been insufficiently elaborated; the stage management of even a simple anecdote makes a heavy demand on 'teacher's tact'; and teacher's tact is more readily evoked by the sound of the teacher's own voice than by any effort of imagination. The skilled teacher may generally rely on mental preparation for her stories, but the novice needs vocal preparation as well; solitude to practice in is as essential to the raw teacher as to the embryo violinist. And even the expert won't wilfully challenge an anecdote quite unprepared.

Narrative is the method specially fitted for stimulating enthusiasm; it is therefore the method by which most heroic material will have to be transmitted. The teacher who is concerned to miss no opportunity of supplying civic inspiration will need first of all to become a skilful storyteller.

(2) Experiment, or 'action-teaching', is usually classified as illustration or expression work; but some action is definitely experimental, not merely expressive or illustrative. The teacher who lines up her class as Greeks and Persians to find out what happened when the Persian wings retired, is really teaching by experiment, and many of the schemes in weaving and pottery worked out in the Transition forms of Kindergartens and the lower standards of elementary schools, belong to the same category. ${ }^{1}$

In the ordinary High School, as it is at present, the exigencies of the class-room and the time-table make it difficult to use this method very freely; but individual children will often spend their leisure on experiments for

1 There are many suggestions for work of this kind in the Industrial and Social History Series (The Tree-Dwellers, The Early Cavemen, \&c.), by K. E. Dupp: and in Handwork in Early Education, by L. L. Plaisted. 

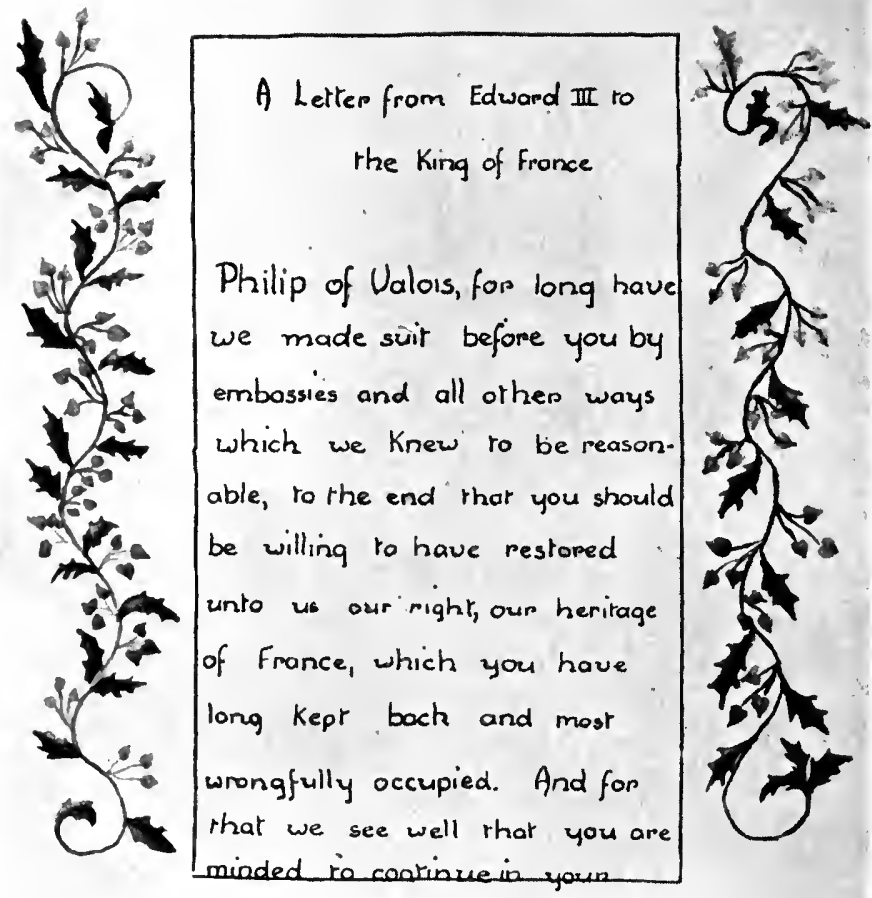

Page from a book made by a child in a series of lessons on the Early History of Books.

The script was suggested by manuscripts seen during a visit to the Rylands Library. The borders were designed after studying illuminated manuscripts in various art books and Museum catalogues. The extracts were chosen from work taken in the History classes.

At the end of the course the books were bound by the children.

[Lent by Miss A. F. Purvis, from work done at the Fielden Demonstration School, Mauchester.] 
the solution of some problem, such as methods of hutbuilding or tent-making; and a class exhibition of such efforts forms a quite adequate incentive.

As class-room regulation becomes less rigid, experimental work of this sort will become more and more possible in all schools. For the civic teacher this should prove a great gain. It demands initiative; it requires and tests concise and realistic thinking in pupils who find the medium of words difficult; and, more important still, by stimulating children to 'live in' a different period, it encourages habits of imaginative reconstruction, and so makes easier the application of sympathy and sense in human relations, personal and political.

(3) By the time children are 9 or ro they begin to observe with interest their own ratiocination; and constructive discussion becomes a popular procedure. The link lesson cannot always be avoided, and 'questioning out' is a good substitute for narrative when traversing arid tracts. To reconstruct the course of events by question and answer is quite an exhilarating form of mental gymnastic; but it needs careful preparation on the part of the teacher $;^{1}$ it is extraordinary at how many points in a question a class can go off at a tangent, unless the question is very carefully worded.

Discussion with rather less guidance is the obvious method for handling cause and effect, and for dealing with the analytical and theoretical work which arises out of economic and constitutional history in the higher forms of secondary schools, in study circles of adults, or in continuation-school classes; and it gives the most natural and effective openings for connecting academic theory with the pupil's own experience. In such work it is often worth while to relinquish the leading-rein almost entirely; dis-

1 Professor Findlay gives a useful example of this 'development' method in Principles of Class Teaching, p. 288. 
cursiveness is a small price to pay for the questions and comments that will sometimes come from apparently stupid people."

Discussion of this sort, when it deals with current events either in the school or outside, is very valuable political training. In defending their own views or allegations, boys and girls are compelled to consider questions of evidence, and to dig deeper into their own minds to get at the principles involved, or to find a re-statement of their case. They are compelled, too, to listen to the arguments of the other side with at least an appearance of patience, and perhaps occasionally to realize that some of those arguments are valid.

(4) Tackling a document combines the pleasures of reasoning with the thrill of the discoverer and of the antiquarian. The attempt to reconstruct the facts and to interpret the record for themselves gives the greatest delight to children from Io years old onwards.

There are many source-books now on the market, and at least one English text-book ${ }^{2}$ is based on the 'source-method'. But it generally pays best to hektograph-and abbreviatethe material you mean to use. If the hektographed extracts are collected at the end of the lesson, and kept for use another year, the amount of labour involved is not very burdensome.

The source-method is most successful where the problems to be solved are quite definite and concrete. A Domesday entry is the best and soundest approach to the study

1 'If you are going to'allow boys to evolve ideas and institutions from their own experience, you must have patience to endure a long journey and to tolerate plenty of confused thought on the way.' - J. H. Simpson, An Adventure in Education, p. 136.

${ }^{2}$ History of England for Schools, by M. W. Keatinge and N. L. Fraser. The Historical Association publishes a selection of documents on separate sheets for class use. These are very serviceable for Sixth Form work; but they are too long to be manageable in lower forms. 
of manorial economy, because it opens on to it through the reconstruction of a particular village. Henry I's Charter (selected version), read carefully, and supplemented with a few pointed questions, produces an excellent catalogue of the grievances under Rufus.

Documents often form a good basis for retrospective

$$
1628
$$

The Dords a Commons in Pavliament assembled.... du humbly pray your most excellent Majesty that no man hereafter be compelled to yield any gift, loan,... tax or such like elzarge without common consent by act of Parliament... r that no freeman in any such manner as is before men. tioned ${ }^{-k}$ be imprisoned or detained; क that your Majesty be pleased to remove The said suldiers.... a that your people may not be so burdened in time to come; $\rightarrow$ that the coinmissions for proseeding by martial law may be revoked an inulled, that hereafter no commissious of like nature may issue

* "withoui cause shown... but that they were deiained by your Maiesty's special command".

Hektographed slip for 'source-lesson' showing method of abridgement. This was used for an introductory lesson on the troubles of Charles I's reign with an upper standard in an elementary school.

teaching. The Petition of Right and the Bill of Rights (both much abridged) provide neat introductions, the one to the early troubles of Charles I and the other to the misdemeanours of his sons.

The chief difficulty with pupils new to the method is to prevent effervescence, and to concentrate attention closely and promptly. A question that begins 'How many' is 
a safe opening, whether it can be solved individually or must be worked out with the teacher on the blackboard. A request to count the population of your Domesday village launches the lesson safely, and leads on to nearly all the topics you want to discuss.

When the outline of the story is already known, a contemporary document is often helpful because it expresses a new point of view; or the comparison of two documents will bring home to the class the difficulties of conflicting testimony. Perhaps most illuminating of all are the cases, such as Froissart's account of the Peasants' Revolt, where a biassed blindness to facts has made possible an attitude to us wholly unintelligible. It is never advisable to make many comments, but boys and girls are quite sensible enough to draw their own conclusions. Documentary study used in this way is a very convincing method of exhibiting the need for tolerance, for thoroughness in investigating evidence, and for care and patience and justice in forming opinion. ${ }^{1}$

Documents must be used sparingly, and worked very thoroughly. But there are many sources other than documents, and the procedure is just as appropriate to them. Brass-rubbings are a specially delightful possession. The Trumpington brass, or any armoured knight, opens well for feudalism. The Woolmen usher in the economic changes of the $15^{\text {th }}$ century, and offer a good introduction to economic theory for adults whose academic interests have been long in abeyance. A series of military brasses supplies an admirable text for lessons on the development of armour, and its social consequences. 'Their size makes them unmanageable in force; but hektographed reproductions fill in gaps and fix memories.

The possibilities of maps as sources are often overlooked. Local street names-the Minories and Moat

1 Cf. Studies in the Teaching of History (M. W. Keatinge). 
Lane, the Priory and Mill Hill, Marshfields and Meadow Road-are incitements, as well as clues, to the reconstruction of the old town; and in some fortunate places these can be correlated with a Domesday entry, and the location of the eleventh-century mill identified by a street sign. Even modern street names-Plevna Terrace, Frankfort Place-give the date of building; and incidentally demand an explanation which forms a useful bridge-head on foreign history and includes information which may make the newspaper more intelligible, and political opinion more intelligent, later on.

A variation of the source-method gives the best introduction to civics in the narrower sense. A map of the town showing the municipal buildings, and a plan of the buildings showing the different departments, form a basis for the study of local government only excelled by a visit to the buildings to collect the names of the departments from the doors themselves.

(5) Individual exploration is probably the best solution for the central problem of civic teaching - the detailed study of local government. This is stubborn material from the teacher's standpoint, for it does not submit readily either to systematic or to generalized treatment. It can seldom be made either picturesque or philosophical. An alternative stimulus must be found, and that of discovery and-of local interest lies ready"to our hand. Let the children find out first from their parents or their friends, who attends to the drains, or builds the schools, or repairs the roads, and it will be possible gradually to push inquiries further home, and discover who pays for such luxuries, and how and when the bodies are elected who administer the money. Such information, if entered into a note-book, and recorded on a wall-chart, will grow into systematic coherence by degrees. ${ }^{1}$

1 I assume that every pupil can have a note-book specially dedicated to 
Even the central government may be approached in this way. A collection of the reasons for which people visit the Post Office furnishes almost as exciting an introduction to Constitutional History as a local election.

The most elaborate individual investigation on local lines has been done by the teachers in touch with the Regional Association. The deliberate and systematic field work necessary for the survey, which they make their pupils' objective, is precluded by laws of time and space in the ordinary High School, but it is very appropriate in study circles of adults; and survey work of this sort should prove both popular and valuable in the Continuation Schools.

Individual investigation of a more academic type is perfectly feasible within the four walls of a class-room wherever there exists the possibility of a form library and of special note-books. The boys and girls should be incited to choose their own topics, and where one's pupils are under ${ }_{15}$ it is best to encourage subjects with clearly defined and rather narrow limits, e. g. a battle or a biography, and to confine the time spent on the private collection of facts to three or four weeks. The production of a model, an illustrated map or a picture, makes a good objective for the weaker vessels; but a large percentage will get much profit, and even more pleasure, from the preparation of short monographs.

Some help is needed in the choice of topics, and this is most conveniently given in a few introductory lessons on the period to be treated; and a certain amount of tact is required to steer the more enterprising away from unmanageable subjects; but after these initial difficulties are overcome, the class will steam ahead with amazing independence, and with very little intervention, beyond an occasional hint as to the books to be sought or the chapters to be avoided.

this study. Such note-books can be made by the class if they cannot be otherwise provided. 


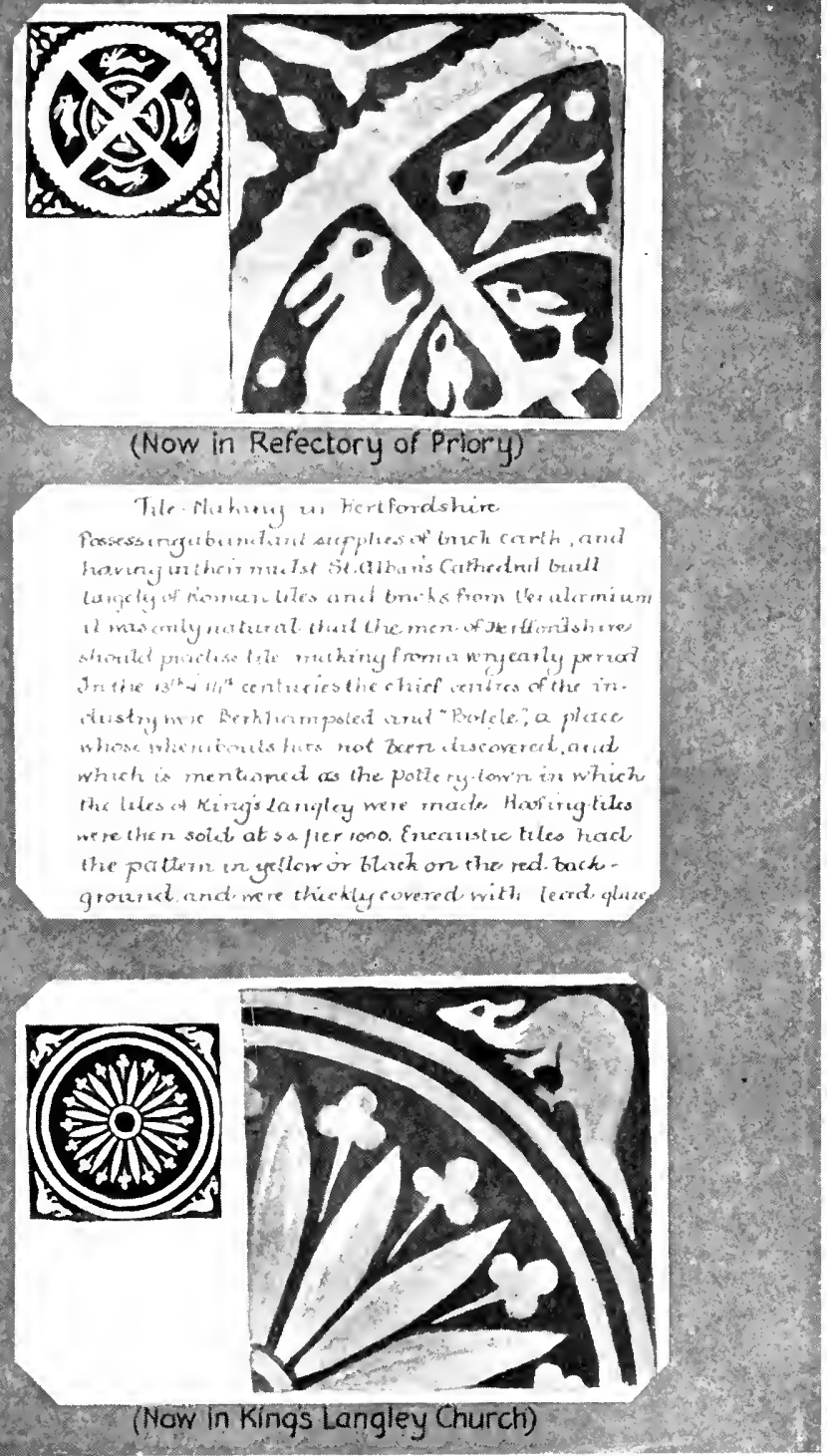

Part of a sheet made for a Local Survey by a girl of seventeen. The paintings were made direct from the tiles. She collected the information for the notes from the nearest public library, five miles away.

[Lent by Miss M. Barker from work done at The Priory, King's Langley. 
When work of this sort is being done in the top forms, access to the school library provides the necessary books. Where the method is used with lower forms, whose libraries are inadequate or non-existent, it answers better to borrow books from the school library for a few weeks than to get leave for the researchers to make use of it themselves. Young students are more easily enticed to browse independently if the books are always at hand and are not confusingly numerous.

More ambitious adventures in this direction have been made here and there $;^{1}$ but these involve considerable periods of private study and much better libraries than most schools can provide. Even attempted on a small scale and on very simple lines, this method has extraordinary value, and will often wake the latent power in apparently dull and difficult young people.

\section{VII}

\section{FIXTURES}

'After all,' he added piously, 'in the Day of Judgement, what will be the odds?'

Mr. Salteena heaved a sigh. 'I was thinking of this world' he said.Daisy Ashford.

WE have outgrown A.L.O. E.'s conception of our pupils as so many heads to furnish; but some knowledge must be as firm as the nails that fasten the carpets. They must make a certain number of fixtures with facts.

One of the earliest problems that confronts the teacher

1 The Historical Association publish an account of the experiment made by Miss Mercier at Manchester High School. . 
who has a free hand is the selection of the stuff for memory work, and of the best method of fixing it. The discipline of History lies mainly in cause and effect, so that sequence is here of the first importance, and most fixtures will be chronological. A few well-chosen and never-to-be-shifted dates make all the difference between ease and acute discomfort in historical thinking; and it is extraordinary.how small a number of fixtures of this sort will keep the rest of the sequence in place.

The Armada and Waterloo and one or two other battles are a convenience; but the dates of reigns, judiciously selected, give the greatest ease of mind for the study of English history. Eight years old is the best time for learning them; and at this age they can be administered, one or two at a time, as a reward for merit and a sign of advancing years. But quite apart from the atmosphere thus created, children of 8 or 9 seem to enjoy a little interlude of mechanical work; and their enjoyment is a strong reason for supposing it healthy. The usual argument against it, that it is bad for them to learn anything of which they do not at the time see the use, does not apply if they are working with a chart, for enough of their stories and dates will correlate to show them how dates 'come in', and they take as much pleasure in filling in their chart as in fitting together a Chinese puzzle.

The old-fashioned chessboard charts are useless : they confuse the eye and so are very little help to the visualizing memory; and they fail completely to give the idea of sequence, which is the main service of a time-chart to young children. Horizontal wall-charts are the best for ,boys and girls under $x_{4}$; perpendicular charts cannot be manipulated by the children themselves, and fail to give the idea of infinite extensibility; but if the class-room does not admit of a horizontal chart, a perpendicular chart is better than nothing. 
From Io or I I onwards, children should use the chart for a more precise fixing of dates and sequences, and they will then need to supplement the wall-chart with time charts ruled in their own note-books; these ought to be filled in with events from lesson to lesson, and though this counsel of perfection is seldom carried out, girls will generally make enough use of the note-book charts to get a good deal of profit from them.

The fixing of facts other than dates can be made easier and more automatic by the use of skeleton notes, especially if the visual memory is exploited by a lavish use of spacing,

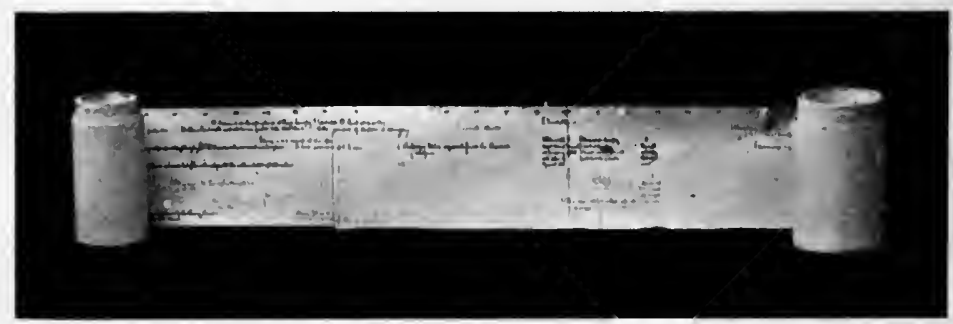

Rolled chart used for field work by Miss Mabel Barker. This chart was made of strips of squared science paper. It is quite portable and its length is not conditioned by the wall-space available.

underlining, and paragraphing. Symbolism is here a help ; crossed swords for battles, clasped hands for treaties, and lovers' knots for marriages, break up the monotony of the script and 'stick'; and children will readily invent new and admirable symbols for themselves.

The most effective skeleton notes are those hektographed by the teacher. These are usually remembered very completely and without any difficulty, so that a class using them has much time for individual reading. Their facility is, in fact, their chief danger, and they are quite pernicious if they deal with matter of opinion: but for matter of fact 
they are invaluable, especially where, as in much foreign history, the ground is new and memory difficult.

Less laborious (for the teacher) and in many ways more educative for the class, a blackboard analysis of the facts at the end of the lesson is also a great aid to memory. Such a summary is very necessary for children under 14, who cannot think and take notes at the same time; and it is a good way of revising the lesson and of showing how to analyse and pigeon-hole information. As such blackboard summaries rarely get transferred to the note-books quite without modification, there is little danger of slavish imitation; and points a child has recorded himself have a good chance of survival.

A certain amount of local inemory is needed if the history that has reference to places is not to be meaningless. Where the facts are static, e.g. the area occupied by a tribe or secured by a treaty, the most effective procedure is to prepare beforehand a coloured wall-map, as simple and diagrammatic as possible, which can be left in the classroom after the lesson: and, if precision of memory is wanted, to supplement this with helitographed replicas which one's pupils can colour for themselves. When it is movement that must be remembered, as in the marches of a campaign, a diagram drawn on the blackboard in the course of the lesson, and if possible while actually talking, is much more convincing and effectual, even though the diagram is very rough or very grotesque.

For memory work, some kind of test must be used. The most economical in time and labour is the 'written VV'. The answers can be written in two or three minutes at the beginning of the lesson, and corrected by exchange of books; but the questions need preparation, since it is essential that they should admit of only one answer, and that it should consist of very few words. ${ }^{1}$ The unwary

1 This method serves if speed is a main object. Interesting (and of 
teacher, who leaves her questions to the spur of the moment, will find herself burdened with a pile of books she must correct herself.

When the school routine does not require perpetual marking, much more entertaining tests can be devised. The most exhilarating is the form match, preferably with captains to organize and pick up sides. A date match can be made a very brisk affair.

A popular test with older pupils is the 'general knowledge' paper. If it consists mainly of such questions as 'Who could not tell a lie?', 'Who never smiled again?', quite unpalatable information, such as a tiresome date or the terms of a statute, can be included: and reiteration in this and other forms, will lodge even these facts safely in time, especially if they can be regarded as humorous.

In preparing for examination, more deliberate memory work than this will be necessary, at any rate until examiners are reformed, and it becomes as much a matter of course that one uses a skeleton chronology in working a History paper, as that one uses a pair of compasses for Mathematics. But rote-work induces a habit of mind inimical to the spontaneous and fertile thinking, the strong enthusiasm, the vivid self-identifying sympathy which civic teaching must cultivate; and the History teacher who is intent on civic purpose will therefore reduce it to a minimum.

course far more valuable) schemes for collective marking are described in An Adventure in Education, p. 123, and in The Play Way', p. 84. 


\section{VIII}

\section{ILLUSTRATION}

One stone the more swings to her place

In that dread Temple of Thy worth-

It is enough that through Thy Grace

I saw naught common on Thy Earth....

Who, lest all thought of Eden fade,

Bring'st Eden to the Craftsman's brain, Godilike to muse o'er his own trade

And manlike stand with God again.-KIPLJNG.

Apparatus is a crutch to the weak and an alpenstock to strong. Its chief defect is that it is so attractive to the novice that she spends too much on it. ${ }^{1}$ A stringent review of costings in time and energy is the best safeguard against this snare, and for this purpose illustrations should be classified by function.

They fall into three categories :

(a) Illustrations lending vivacity and vividness.

\section{elaborating detail.}

(c) " giving a bird's-eye view of a whole.

(a) Some portraits-Richelieu's or Charles I's-are so indicative of character that they might almost be used as sources, if one were not afraid to brush the bloom off an impression. But most pictures of people and places-and nearly all relics and literary illustrations-belong to the first class : their function is fulfilled when they have made their reference more human, more interesting, more alive.

The post-card craze has made pictorial illustration of all kinds easy to obtain, and any one who taps advertisements and catalogues can have pictures for the trouble of cutting out and mounting. Indeed, the difficulty is not how to

: I gather that this danger is less serious when it is 'he'. 
acquire, but how to keep: a system of classification, thought out early.in one's career, is the only guarantee of an available collection.'

Literary illustrations, if they are to be used in class, must be highly selected. For long descriptions, most classes prefer the extempore teacher; Macaulay and some of the mediaeval chroniclers are almost the only writers who can safely be interjected in bulk. ${ }^{2}$ But a few sentences from a contemporary-Alfred's allusions to his 'nine general battles', the Anglo-Saxon Chronicle's comment on Domesday Book, the squabbles of Henry and Becket, Cromwell's letter to Hazelrig before Dunbar-give great vitality and emphasis: and where the quotation has eloquence, as in Elizabeth's speech at Tilbury, or in Cromwell's reference to the Ironsides-or anything of poetry, ${ }^{3}$ as in Marvell's allusion to Charles I-it makes an impression never to be effaced. For older pupils, one can safely add to one's repertory anything, whether anecdotal or descriptive, which throws sidelights on character, or which brings into relief the manners or standpoint of another century; and with them, much more than with

1 Such illustrations can either be affixed to the chart or the notice board for study after the lesson : or, in the case of post-cards or small mounted pictures, call be handed round in class. The latter method has the advantage of giving more opportunity for movement; but it may give an impression of disorder if a visitor happens to arrive.

2 Youngish children generally enjoy anything gory : e.g. the description of Stephen's reign and of the death of Becket have an unfailing vogue. But they like their horrors with plenty of movement; passive atrocities, e. g. sufferings during an epidemic or a siege, cause-not disgust but-boredom. This cannot always be attributable to the style of the writers: e. g. Pepys on the Fire is appreciated, while his account of the Plague is received with polite indifference.

3 Extracts from the Legend of the Three Companions and the Little Flowers of St. Francis belong to this category. But they need a good deal of selection and abbreviation, and some softening of their more distinctively mediaeval features. 
younger boys and girls, cross-references to literature are keenly appreciated.

A good deal of literary illustration is best taken in. dividually. This applies specially to non-contemporary treatment. Passages from Scott or Kingsley, which are extraordinarily stimulating and suggestive to children if read privately, fall very flat in class, however carefully they are selected and prepared. But children who have any taste for history will generally read historical novels, and will sometimes read historical plays, if a form library makes them accessible. ${ }^{1}$

The systematic correlation of History and Literature does not pay even from the historian's point of view; but, where the history teacher controls the literature lesson, both subjects gain from an occasional interlocking; Julius Caesar, Richard III, and some of the Coverley papers are good cases.

Correlation between History and Craft-work is much more fruitful, and the Handwork and Needle-craft lessons often ask for a theme. Costume worked out in the sewing class, fortification studied as woodwork, may be good handicraft as well as good history.

Relics are disappointing as illustrations. The class that thrills to hear that you have seen a copy of Magna Carta with your own eyes, will regard a real stone arrow-head with strange frigidity. Possibly they need the medium of another personality and another enthusiasm to warm them to response. You get the best return for your relics if you display them co-operatively. A form exhibition, to which every one is invited to contribute 'anything very old and historical', will produce great animation, and an astounding number of antiquities.

The converse is true of visits to historical remains : they

${ }^{1}$ In forming such a library Nield's Guide to Historical Novels will be found useful. 
are far more appreciated if indulged in by twos and threes. Grown-up people appreciate the conducted tour, but it is apt to fall very flat with children, unless enlivened by some imaginary danger, or some defined object. As a ferociouslooking cow cannot always be provided, it is well to go on purposes of research. The need to investigate an obscurity or to collect drawings for a survey alters the whole social

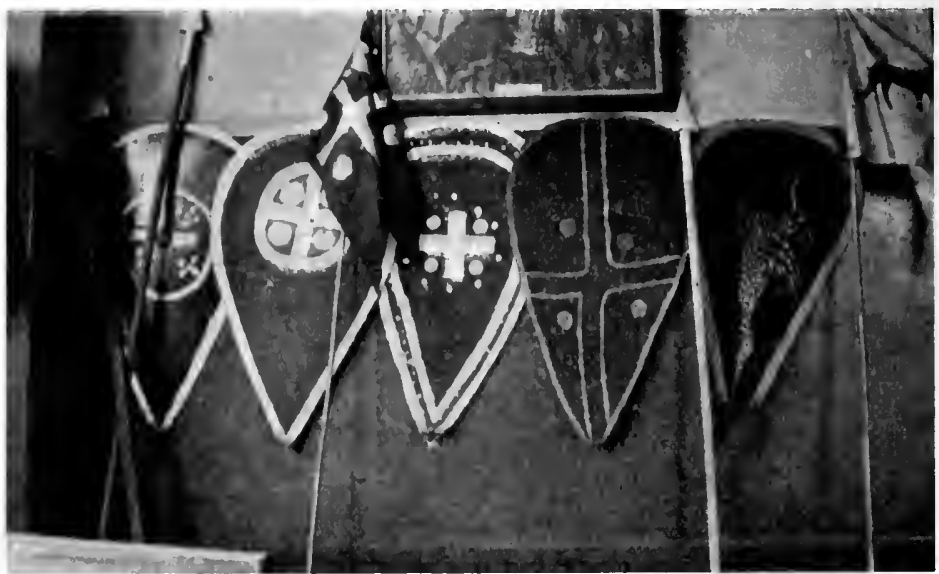

Handwork made in connexion with an intensive study of the Norman period.

Weapons and banners studied from the Bayeux tapestry. (Lent by Miss A. Purvis and Mrs. John Reade, from work done at the Fielden Demonstration School, Manchester.)

atmosphere. But better than the expedition to a ruined castle or a famous abbey, is the incidental observation of antiquities near at hand. Many young things will thrill to the discovery of a half-timbered house or an Elizabethan chimney; and local archaeologizing is worth more than many excursions, however carefully planned.

(b) Explanatory illustrations must generally be prepared 
ad hoc, though a certain number of useful wall-pictures are published, and brass-rubbings are invaluable for costume and armour, and post-cards for architectural detail. ${ }^{1}$

The bolder and simpler the diagram the more effective it is likely to be; finish and elaboration either pass unnoticed, or actually distract the attention of the class. Indeed, the most telling diagrams are those that are sketched in during the lesson. If the function of the diagram is merely to clear up a difficulty, the children care so little for beauty of effect that the problem becomes mainly one of finding an angle at which one can both talk and draw. ${ }^{2}$

If the subject needing illustration is too elaborate for blackboard treatment, hektographed drawings are often the quickest and most effectual solution: with pupils under 12 it is well to arrange that they do some work on them themselves; cutting out, colouring, or filling in, ensures study.

While it is important that diagrams should avoid elaboration, it is equally important to ensure that they contain the relevant features; this is not so simple as it sounds, because one's authorities sometimes omit them in their illustrations or give them so overloaded with other detail that their application is obscure. The design of a concentric castle is unintelligible to the immature unless the relief is clearly shown: in some cases, e.g. Château Gaillard-this should be indicated in section as well as on plan if its features are to be adequately appreciated.

Where a supplementary diagram of this sort is needed, and gaps must be filled in from the teacher's imagination,

1 Where it is important to get beauty of effect, it is well to mount the post-cards. Brown paper supplies the most effective mounts. They can be prepared very quickly and neatly if a stout post-card with its corners snipped off is used to guide the pen-knife in making the corner cuts.

2 But it must not be forgotten that they always care for coloured chalk. 
because verification is impossible, it is a good device to give the authoritative portion in hektograph, and the supplementary and unverified addition as a queried diagram on the blackboard. ${ }^{1}$

Whenever a plan is simple enough to be taken down with sufficient accuracy by the class-e.g. a map of Crécy or Lake Trasimene, or a section of the Great Pyramid-the blackboard should be used. It saves the time of the teacher and the memory work of the pupil, who is more likely to retain without effort facts he has mixed his labour with.

The production of wall-maps is less burdensome than it sounds, as the same maps are needed year after year; and good cartridge-paper lasts longer than most teachers. The less maps are elaborated the better; a twopenny paintbrush dipped in the inkpot gives the best outline and the right amount of detail. Maps are generally most useful if they do not show names: but important physical features should be indicated.

The easiest way to enlarge a map is to transfer it from the atlas to the squared paper prepared for scientific diagrams and to rule your cartridge-paper in squares to correspond. Some maps, e.g. England and France, are so constantly needed that it is worth while to keep a tracingpaper outline ; this lasts for years, and if it tears is easily mended.

1 Hektographed diagrams and illustrations can be produced very rapidly if the drawing is made directly on to the tracing-paper with hektograph ink. This is perfectly easy if a mapping nib is used. Large pieces of tracing-paper require some management if they are to go comfortably on to the hektograph jelly, as they are apt to get bubbles of air under them. Pieces three or four inches square present no difficulties; indeed they economize labour, because as they are transparent enough to show when the ink begins to spread, they can be left on to the last minute, and they thus give the maximum number of reproductions. 
Maps should always be coloured. Crayons give better colour and keep much cleaner than paints. ${ }^{1}$

(c) A good many diagrams aim not at clarifying detail, but at giving coherence and comprehensiveness.

Most diagrams of this sort are symbolical ; e.g. diagrams showing the 'feudal ladder', or the swing of the pendulum in the Hundred Years' War. They are often useful as the summary of a lesson; but they should never be transferred to the note-books of a class. Such symbols are serviceable to their originator; but it is a dangerous and desiccating process to think in other people's symbols, especially if you are a child and the other person is grown-up.

Many synthetic diagrams, though symbolical as wholes, are representative in their parts. This is true of pedigree diagrams, showing the history of towns or larger regions, and of Professor Geddes's 'valley sections', illustrating the connexion between geography and industrial developments. Such diagrams do not form good 'sources' or texts, but they are very useful either as a summary or as a preliminary to a series of lessons. Left in the class-room for leisured study, they give a bird's-eye view of the whole subject, clear up and illuminate details, often start new trains of thought, and invariablỳ arouse much interest. But they should not be copied unless they are to be used as a type of which one's pupils are to make their own variations.

Where such diagrams have a social reference they are often very stimulating and suggestive, especially to adults,

I It saves trouble to keep some wooden laths for use with cartridgepaper maps. They should be made in pairs about $3 \mathrm{ft}$. long and should have a couple of rings screwed into each. If these are fastened to the top and bottom of the map with drawing-pins, it can be hung up and the weight of the bottom lath will keep it unrolled. Laths about $\frac{1}{3}$ in. thick are heavy enough to weight the map and light enough not to tear it, even if the map is rolled up on them between lessons. 
Z

히니 द्व os baग
shomkund pooy

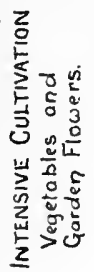
jouns

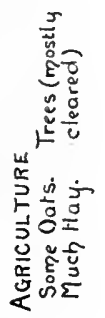

$\frac{u}{x}$
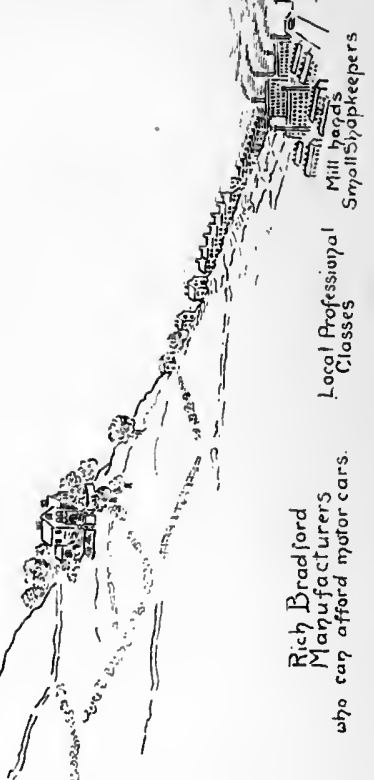

4 (I)

बiv

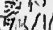

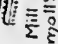
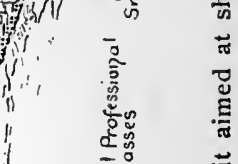

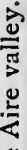

$\therefore$ \&

in $E$

을

is

导

no

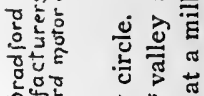

员品

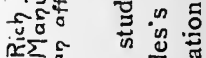

उे

¿ $<$ पु

ร

ป ن

is is

* हु

$\div$ ษ

मे की

$\cong \quad$ 苛范

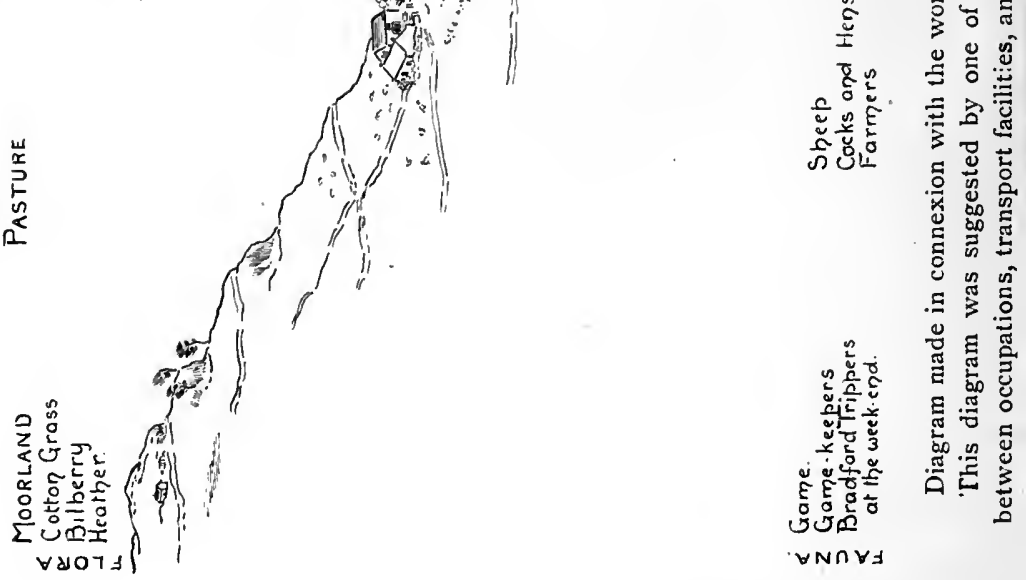


and for some minds they form the easiest approach to sociological interests. This is conspicuously true where an attempt at adaptation is made; in such cases they will sometimes give an entirely new outlook on the social group and a new significance to membership of it.

It is often worth while to summarize a series of lessons to children in some form of co-operative diagram. The very charming models of pre-historic villages, mediaeval fortresses, Canterbury pilgrimages, sometimes set up by younger children, really belong to this category. Even under the conditions which prevail in the average secondary school, many of the advantages of this method can be obtained, if the work is carefully schemed. Children whose stories of the Persian Wars have included studies of the costume of the Immortals and of the Spartan men-at-arms, will produce very decorative effects, when they collaborate in a picture of Thermopylae, with the figures grouped on a crayon background. The eleventh-century village, worked out from the Domesday record and the modern map, can be interpreted as a diagram landscape which yields a fine colour scheme: and if the children have been getting at the form of the dwellings, and the architecture of the Norman church, these too can be drawn and cut out and stuck on in place.

The danger of such work is that it will be cherished too carefully. The naivete, which is one of its charms, becomes a snare if it is kept too long. During the making, it was an incentive to thought; completed, it expressed and summarized thought; but preserved, it only limits thought. If such treasures are to be hoarded, it should not be in the class-room. Only fresh work should be allowed there. 


\section{IX}

\section{THE YOUNG IDEA}

Accustom the individual to be nose-led and spoon-fed, and democracy is a mere pretence. The measure of democracy is the measure of the freedom and sense of responsibility in its humblest citizens.-GalsWORTHY.

THE prayer of Mrs. Shelley for her son-'Teach him to think like other people'-is one few mothers need utter. Most of us are only too ready to 'think like other people': it saves so much trouble of action and even more of mind. But whatever may have been the case in the past, the herd instinct in thought is an unmitigated danger to the group now; and even for the individual, happiness will hardly come till he has found himself. Children need to be accustomed young to some independence and individuality of taste and thought.

For this, History does not supply the easiest material. Its factors are too complex, too difficult of isolation and abstraction, to make it the best medium for cultivating independence of observation or of judgement; and it demands too much initial grind to be a facile starting-place for originality in imagination and expression. Science will serve the one purpose better, and literature or the art and craft subjects, the other. The stuff of History is too much like that of human life itself.

But its very complexity makes it good ground for the discovery of tastes ; and for this purpose the cult of collections forms a good nodal point-the less specialized the collection the better. Children will find out what they really like doing when they are rummaging for contributions to a form Museum, collecting information for a local survey, or pursuing specimens for a History scrap-book. History 
albums-contents only limited to 'anything which has to do with History'-have a great vogue at 12 or 13 .

The accumulation of scalps is obviously the most exciting form of collecting, and to many children in the Thirds and Fourths a book read is still a scalp. A monthly comparison of book lists is an incentive to excursions into literature that would not otherwise be taken, and will often show people, who had never before suspected it, that they really enjoy some kinds of reading.

Originality of imagination and expression is most readily aroused in the effort to modify a type form. Boys and girls who would shrink into shyness at the thought of purposively creative work, will originate freely to adapt a diagram or imitate a ballad. ${ }^{1}$ For older and more selfconscious people, parody is sometimes the easiest beginning. It affords additional camouflage for personality and substitutes abandon for inhibition.

Imagination plays far more easily and spontaneously with the support of a convention. ${ }^{2}$ It is important to

1 The impulse to adapt is charmingly illustrated in Lady Glenconner's Memoir of Edward Wyndham Tennant.

'The nursery-maid used to sing a country song that had some such lines as these :

Then Robin got up with a hippity-hop

H'm-ha-hippity hop ;

When there came an old woman to gather them up $H$ 'n-ha-gather them up.

It was Easter morning and Bim was heard singing cheerfully :

So Jesus arose with a hippity-hop

H'm-ha-hippity hop;

With all the good angels to gather Him up

H'm-ha-gather Him up.'

That the capacity does not die out in older children the Perse Playbooks abundantly prove.

2 Perhaps this accounts for the more general artistic production of the Middle Ages; and possibly the existence of earlier renderings was a factor in the achievement of Shakespeare. 

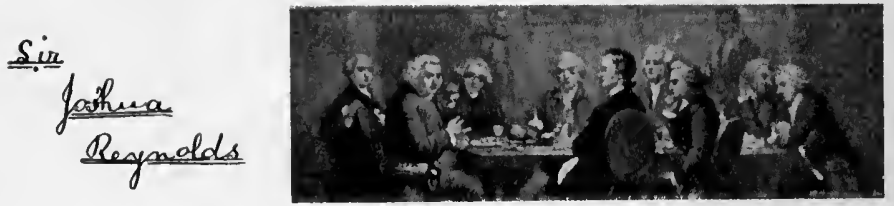

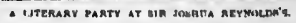

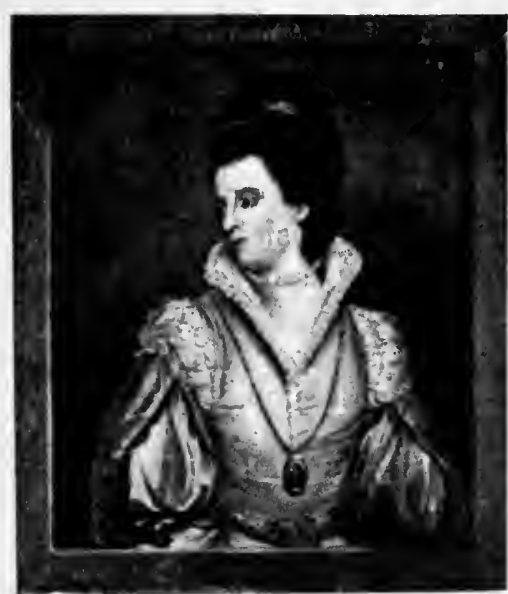

Singoshua Reypolds. a celebra ted inglish painter, was ban at Plymton, in D cromshire, fuly 16." 1723. We was intended by his father for the medical profession; but manifesting a decided taste for art, he was. at the age of seventeen, placed with Hudsow, then the frim cipal partrait - painter in London. Hte remained with him but three years, whem. Q Shecimen of the work of Sir prhua Revinalds. upon some trifling desagreement, he returned into Devonshire.

Sir Goshua Reynolds' paintings werecheefly portraits. Hte died in 1792, aged yo.

Page from a child's history scrap-book. 


\section{Eemeral Wolfe.}
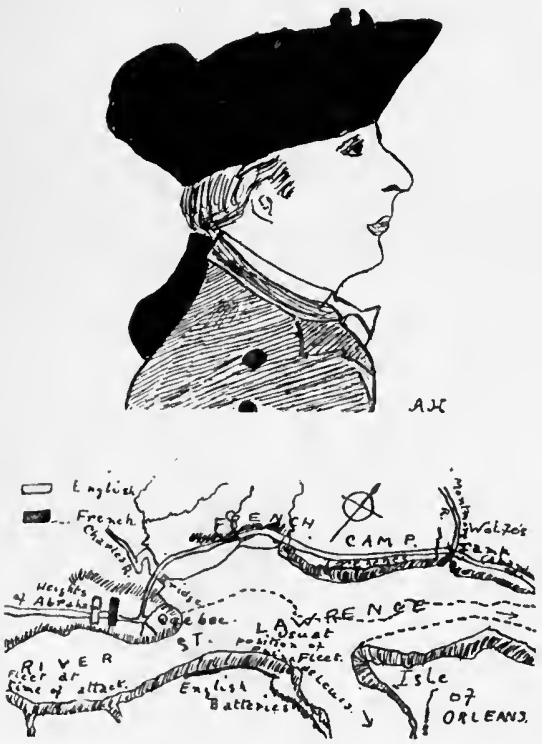

rolfes operations at Queber.

Ihe toattle of Quebec. 404 .

In 1959 . Tolfe was ordered by Pitt to take Quelec.

Quebec was well fortified, and a strong Trench army was posted below the town, between the rivers $b$ harles and Inontmor.

Page from a child's history scrap-book. 
remember this in setting constructive work: letters descriptive of historical events, dialogue between imaginary characters, are good subjects,' but they must either be elaborated co-operatively in class or, if the work is to be individual, it must have a model. ${ }^{2}$

He writeth best who cribbeth best

Ideas both great and small.

For the great mind that wrote them first

From Nature cribbed them all. ${ }^{3}$

Here to a great extent lies the virtue of dramatization. The material and the form are given; while the work of adaptation and interpretation leaves scope for invention. This often shows itself more clearly in the quaint and witty fancies and symbolisms of children who extemporize the 'acting out' of a story, than in more evolved dramatic efforts. ${ }^{4}$ For the latter, a highly conventional form-a pageant or a masque-is often a help, both to the writers and to the actors.

It is a fairly safe rule for novices that dramatic work should be either very realistic, or completely conven. tionalized, and this is true of the accessories, as well as of

' A 'contemporary newspaper' seems a promising suggestion (cf. Political Education at a Public School, V. Gollancz and D. Somervell, p. 34). The idea would probably develop well co-operatively.

2 Even in such flights of imagination as are illustrated in The New Narcissus (C. C. Martindale, S.J., 'The Goddess of Ghosts'), it is worth noting that the school-boy begins by imitating an historic original.

3 I have been unable to verify this quotation.

4 I was once watching a student in training dramatize the Persian Wars. Her discipline was a little weak and the rendering of the earlier days' fighting became too realistic. While she was separating the combatants I noticed in the far reaches of the class-roon a boy on his face, worming his way between the desks and the wall. Imagining that he had deserted the lesson, I went to ask reproaclfully which side he was on. My suspicions were quite unfounded. He was Ephialtes on his way to betray the Spartans-and very much afraid lest my ill-timed inquiries should have drawn their attention! 
language and action. From the historian's point of view, costume should be either purely symbolic, or genuinely and accurately antiquarian. The master's gown that represents the funeral mantle is good; so too are the borders copied from a Greek vase, or an Assyrian carving, the armour studied from an illuminated manuscript or a monumental brass; even a combination of symbol and realism is permissible. But the pretentious anachronisms of fancy dress cannot be borne. ${ }^{1}$

Teachers of young children sometimes get good results by encouraging them to make imaginative pictures of historical events. When this occupation has 'caught on', it is well worth while to introduce them gently to the idea of getting the detail historically accurate : an anachronism they themselves can recognize furnishes a good opportunity. Some of them will generally take kindly to the idea of hunting for examples of costume and armour, if one or two good illustrated books-e.g. the illustrated editions of Green and Social England, and Gardiner's Students' History -are kept in the class-room : and many of the children's books now issued make use of some contemporary illustration. A hobby of this sort, once started, appeals strongly to certain children.

1 The classic account of the dramatic method is The Dramatic Method of Teaching (H. Finlay-Johnson); The Play Way (H. Caldwell Cook) gives very suggestive and varied hints on dramatic treatment.

The special difficulties, and the special advantages, of the method are indicated in the Ruthless Rhyme (M. Morton):

Tom Brown, a boy who seldom tries,

Was taught by me to dramatize;

$\mathrm{He}$ acted Brutus to the life,

And killed Joe Turner with a knife.

Of course, he overdid the part.

But that's not what I took to heart.

I think it was a beastly shame

To say 'The Teacher was to blame'. 
When we are out, not for individuality of taste or originality of expression, but for independence of judgement, the problem is less simple. Something can be done by the mode of presentation. If one's boys or girls are charting their facts, they can observe for themselves that the East was in a ferment round about 2000 B.C., or that 1848 was

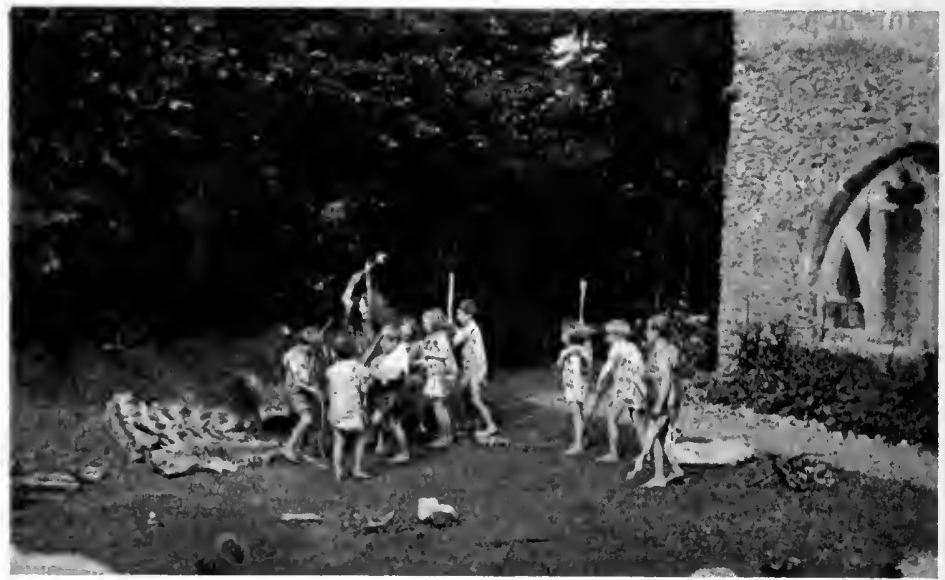

Preparing or a mammoth hunt.

Scene from a Pageant got up by the staff and pupils at The Priory, King's Langley (one month's intensive work based on four years' regional study).

The stone in the middle is a stone-age kettle, hollowed out by the children with flints, and used by them for boiling water with heated flints.

a year of Revolutions. Something can be done by setting questions, especially questions on cause and effect, for which the answers cannot be collected ready-made from a text-book, but require personal investigation of chronology. Here and there the demands of a debate will stimulate to solid thinking; and informal discussion in class is often very provocative. But generally, individual attention is 
needed, and it is in private and incidental conversations that the best work is done.

Few teachers can do much, and the History teacher less perhaps than others. Originality cannot be generated, it can only be inhibited; and so many of the best influences of the good school and the good home make for conformity to type that the business of inhibition is always going on. But even the History teacher can see that the stimuli are varied enough to leave no potential originality untouched, and can help to break through the identification of heresy with individuality, and of conformity with good form, and may here and there encourage a struggler in the effort to find for himself a valid test of judgement.

\section{$\mathrm{X}$}

\section{BY-PRODUCTS}

The Extreme as a personal ideal for those who are called by it is a necessary complement of the Mean in public policy.-Graham Wallas.

THE Blue Bird was found in the cottage kitchen; and though our objective is strictly utilitarian, we shall find beauty and pleasure among our by-products. In making citizenship the main issue, we do not close the side issues into culture and the interests of the scholar and a crowd of leisure-hour pursuits. The main product of civic studies should be the citizen in whom the inspiration to civic service is strong and unflagging, whose action is courageous and resolute, whose thinking is just and clear-headed and endued with common-sense, whose sympathies are too wakeful to permit him to lapse into cruelty or callousness, and whose information will serve to make his virtues an asset to the community and not merely a torment to himself. But our efforts to make our teaching vivid enough to kindle sympathy, definite enough to cultivate hard thinking, 
varied enough to stimulate individuality, must naturally open many windows on life; and through some of them the wind of the Spirit will blow.

A chance historical curiosity leads one to the hobby of a lifetime. Another first learns the happiness of creative work in the lowly effort to compose a diagram, to scheme a costume, or to adapt a scene. The excitement of research, the thrill of discovery, need not remain the preserve of the specialist; local history is a mine with many veins still unworked, yielding to patience and good sense sometimes more readily than to the profundity of scholarship.

The humbler lore of the historian gives interest to the dullest neighbourhood. Eccentricities of dialect and phrase reveal their meanings. Oddities of local tradition supply fresh clues. Even the contour of a pasture or the curve of a street will have something to say. Peculiarities of local architecture gain fresh vitality, and fashions in window and roofline derive a new significance, as one learns to trace their correlation with the expression of the country-side and the character of its people.

For very many, Beauty is first discovered in this search for something else. With the attention fixed to recognize a style, to interpret a symbol, to catch this or that mark of development, comes the quiescence on which Art can do its perfect work, till the student absorbs serenity under the high vault of Durham, and becomes attuned to the poignant loveliness of early Gothic, or learns the delight that hides with Frideswide among the leaves and tendrils of her shrine.

Best gift of all, comes realization of the kinship between the land and its children. It calls to us in towns and villages, with their centuries of associations, and in unknown fields and hedgerows, as we learn to catch the echo of the labour and the life of the forgotten dead whose blood we share. 


\section{B Y - P R O D U C T S}

Perhaps the bond is closer still, and it is no mere fancy that proclaims that

Deeper than our speech and thought, Beyond our reason's sway,

Clay of the pit whence we were wrought Yearns to its fellow clay.

Possibly in that neglected yearning lies one explanation of the strain and disharmony, which psychologists have noted in modern life: and it may be that the solution of the problem lies in the discovery of the bond with the Motherland as an incentive, and its recognition as a claim, not so much to the reconstruction of our personal life as to the reconstructive service of the Commonwealth. 


\section{DETAILS OF INDIVIDUAL LESSONS}

(i) Revision Lesson on the Battle of Hastings, based on the Bayeux Tapestry.

[Notable events which have an effective central episode are often stale through much repetition, especially with pupils who are or have been in an elementary school where the concentric system prevails. In such cases the 'source method' often solves the difficulty, supplying both the fresh approach, and the new material.]

[For Lower Forms or Middle Standards.]

Apparatus. Map of Europe.

Wall-picture of Death of Harold from the Bayeux Tapestry (published by Horace Marshall).

I. Get the class to recall the Normans and their place in the world, referring to the map. E.g. 'Find Denmark'. 'Why used the English to be afraid of the Danes?' 'Where else did the "Danes" come from?' 'What else are they called?' 'Show other places that the Northmen conquered.' 'What are the Northmen who settled in France called?'

1I. Point out that the Normans were extraordinarily quick to learn from the French and to improve on what they learnt, especially in building and fighting. We know a good deal about their methods of fighting from a wool-work picture made to ornament a church, and to hang round the Nave above the arches. (It is worth while to give this with a blackboard diagram; and 
even, if the children are intelligent-or very blasé-to give the names of the parts, both because this forms a bridge-head for architectural teaching later on, and because the new work gives relief, and even an element of surprise, to the familiar stuff which is to follow.)

The embroidery was put on a long narrow strip of material, with the pictures coming one after another: first, the reasons for the war; then the Normans getting ready and crossing the sea; then the fighting itself.

By this time some, or all, of the class will have recognized that they know of the tapestry, and will be agog to give its name.

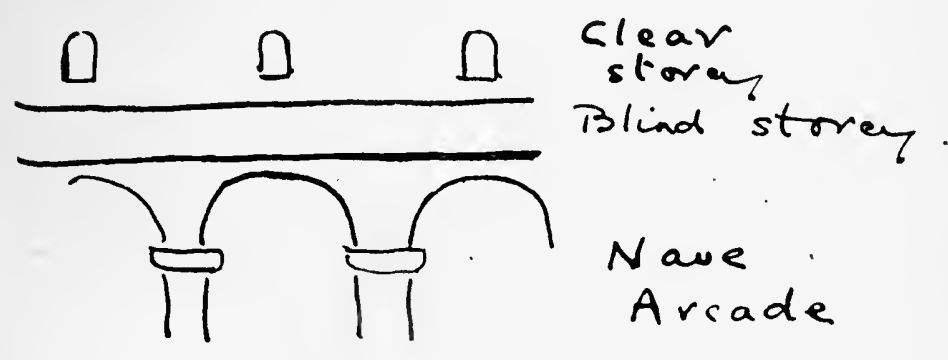

III. Piclure of the Death of Harold.

(a) Get the class to identify the scene depicted, and' to find Harold.

'How do you know it is meant for Harold?' will produce the story of his death.

(b) Lead the class to identify the other figures in the picture.

E. g. 'Who is the man standing by Harold?' 'What is he doing?' 'What is the pole he is holding'? (As the children's views on representation are still fluid and unhampered by convention, they often have less difficulty than the teacher in connecting the pole with the floating 
and rather detached looking monster, and identifying them as Harold's standard). 'Find another Englishman in the picture.' Similarity of equipment makes it easy for them to recognize the fallen man as English.

After this they will readily identify the horseman as Norman. 'Did you know before that the Normans used horses in battle?' will almost certainly produce the story of the early charges on the shield-wall. If this fails, the early stages of the battle can be recovered by way of the shield wall itself. E. g. 'What is this on Harold's arm ?' 'Had many of the English shields?' 'What for?' 'How did they use them at the beginning of the battle?"

(c) The breaking of the shield-wall must next be recalled. The memory of this has often lapsed; and sometimes more than one mode of recall has to be tried. "If the Normans could not get through the shield-wall, how did this Norman get on to the hill?' will probably produce the story; but it may have to be helped out with questions on the boredom of the English when made to stand in line, and the temptations they were under to break their ranks.

When the three outstanding stages of the battle have thus been recovered, it is a good plan to recapitulate them in order; because the better the children know them, the more helter-skelter will have been their account of them; and some confusion in the minds of the less well-informed is inevitable.

[The points can be driven home by extracting from the tapestry the sections showing the English shield-wall with the Norman attacks, and William raising his nasal. These can easily be reproduced with tracing-paper and hektograph ink. The Book of the Bayeux Tapestry (Hilaire Belloc) gives them, panels $63-4$, and 70 .

If the wall-picture is not procurable, it is possible to take the whole lesson from hektographed reproductions. But a wall-picture is more convenient, because it is possible 
for teacher and pupils to point out the objects they are alluding to.]

IV. Discussion on Reasons for the Norman victory.

This should bring out, among other reasons, the difference in equipment and greater skill in its use. If the children compile, from the picture, comparison columns of English and Norman arms, it will become apparent that the Normans differed from the English mainly in their use of cavalry and archers: the story of the battle will have shown that they owed their victory largely to the fact that they learnt how to employ these in battle earlier than the English.

[With pupils over $\Upsilon_{4}$, work of this sort should include some consideration of evidence; e. g. the story as given in the tapestry can be compared with the traditional English account; or the date of the tapestry can be discussed with special reference to armour. Even before I4, many children will take an interest in such points; but they cannot usefully be discussed systematically with a class before this age.]

(ii) Introductory Lesson on the Religious Difficulties of the Seventeenth Century, based on Costume.

[For Middle Forms or Upper Standards.]

Apparatus. George Herbert's Poems.

Coloured wall-pictures of Cavalier. (This can easily be made in coloured chalk from any illustrated history or book on costume.)

\section{Picture of Cavalier.}

A study of the costume is best opened by dating the period; 'When did people dress like this ?' will generally produce, among other guesses, an approximately correct answer. 
The class should enumerate in detail the Cavalier's garments, their adornments and colours, discussing the way they are made, and should sketch the costume in their note-books.

Discussion on the probable characteristics of people who dressed like this will generally produce suggestions that they were rich, gay, and liked things very pretty, or 'very fancy'; it is usually possible to get children to notice that the gay colours form an attractive scheme, and the elaboration and ornament a harmonious and graceful whole.

II. The love of beauty and elaboration, as one of the characteristics of the period, needs emphasizing.

If there are reproductions of Vandyke portraits in the school, these can be referred to, noting Charles's love of pictures. If there are Jacobean houses in the neighbourhood, these can be discussed. Jacobean wood-work is also helpful.

In all schools the poetry of the time can be used in illustration. In many schools the children will already have a nodding acquaintance with it: they will have been told about the masques, or will have come across verses of Herrick in their anthologies. It should be referred to in order to remind the children of its music and quaintness and charm; and with many children it is also worth while to note the classical allusions and the elaboration of the imagery.

It is next possible to bring out that the poets and artists of the time were constantly trying to match the appearance of their work with its spirit; and that they carried this idea sometimes to fantastic lengths-e.g. they not only filled their poems with pretty fancies and pretty sounds, but even occasionally tried to make the shape of the verses on the page pretty and symbolical. George Herbert's 
'Altar' and 'Angel's Wings' should be shown in illustration.

III. It is now safe to pass on to the question of religion.

'What would these people want their churches to look like?' The class will readily suggest that they would want them beautiful and full of adornment. George Herbert's 'Church Floor' should be read:

Mark you the floor? That square and speckled stone

Which looks so firm and strong

Is PATIENCE;

And the other black and grave, wherewith each one

Is checkered all along,

HUMIL.ITIE ;

The gentle rising, which on either hand

Leads to the choir above

Is CONFIDENCE;

But the sweet cement, which in one sure band

Ties the whole frame, is LovE

And CHARITY.

Very little comment is necessary to make the class see that the ornament of the church was important to George Herbert for its symbolism as well as for its beauty.

'What sort of services would they like?' The class will probably at once suggest much music and many hymns. It is valuable to bring out at this point that the Cavaliers also liked to express their feelings in posture, attaching great importance to kneeling and bowing at the appropriate points in the service.

-By this time those members of the class to whom the Cavalier attitude in religion is naturally or by upbringing uncongenial, will be sympathetic; and they will be prepared to entertain the idea that the Cavalier felt that the adornment of his church and of its services not only 
expressed and symbolized religious feeling and religious virtues, but also helped him to cultivate them; that he bowed in worship and knelt in prayer both as a sign of reverence and humility and as a means of attaining them.

It is well to close the lesson by letting the class take down Herbert's 'Church Floor'.

[In such a lesson, the phrasing used in conversation, the range and character of the allusions, and the kind of individual work which can be set as 'preparation', will vary greatly with the age, the attainments, and the social background of the class. But a lesson on lines of this sort seems to be the most helpful approach to the religious quarrels of the Stuart period for most pupils under 16.

It is of course essential that the Puritans should be treated as carefully and as sympathetically as the Cavaliers.]

(iii) Introductory Lessons on the Mediaeval Village, based on the interpretation of a Domesday Entry. Example-Leeds.

[For Upper Forms.]

Apparatus. Hektographed translations of the Leeds entry.

Small street maps, or a large wall-map, of Leeds.

Translation of the Leeds Entry.

In Ledes 10 carucates of land and 6 oxgangs to be taxed.

Land to 6 ploughs.

7 Thanes held it in time of King Edward for 7 manors.

27 villans and 4 sokemen and 4 bordars have now there I 4 ploughs.

There is a priest and a church and a mill of 4 shillings and Io acres of meadow.

It has been valued at 6 pounds, now 7 pounds. 
When this has been read it is well to revive recollection of its background by translating the title of the Ely Inquest, ${ }^{1}$ emphasizing by recapitulatory questions

(i) the method of collecting information;

(ii) the points on which information was required.

\section{'Why was the Book made?'}

The class can infer the answer from the first sentence of the entry, and from the nature of the questions asked.

At this point, a reading of the A.S. Chronicle's comments on William's performance affords amusement, and can be compared with the latest Budget fury.

The value of the manor should be noted. The class will probably know that an increase in value is unusual in this neighbourhood after the harrying.

\section{'What was the population of Leeds?'}

Discussion of this question will involve some explanation of the terms used in the entry; but at this stage of the lesson the explanation should be made as terse and elementary as possible.

When an estimate of the total population has been formed, it is possible to provide an illustration of the smallness and remoteness of the place, if hektographed facsimiles have been made of the ordinary Domesday entries of the district, in column and carefully rubricated, and of the Leeds entry, written rather badly across the bottom of the page without rubrication. A comparison of the two suggests that Leeds was overlooked at first in making the record, and only scribbled in as an afterthought later on; and this leads naturally to the suggestion that a similar explanation may account for the fact

1 Given in Stubbs's Charters. 
that Leeds was not lying waste. [N.B. In preparing work of this sort, it is always worth while to look up a facsimile if one is available.]

[It is not possible to get much further in the interpretation of the entry until the method of agriculture is understood. It is advisable to treat this in very broad outline at first, leaving difficult questions till later. The reconstruction of the mediaeval map forms a satisfactory objective; an approach through the question of wealth gives the most convenient, and most easily remembered, evolution of the subject matter.]

'What did the ordinary well-to-do villager possess?'

A blackboard list should be worked out in discussion with the class.
e.g.
(i) House, with yard and its contents;
(ii) Animals; this leads, via provender, to
(iii) Share of the pastures and woods;
(iv) Share of the hay from the meadow;

and then, by way of the family's own food to the crops and (v) Arable land: discussion $r e$ crops brings out the backwardness of farming and the consequent three-field rotation; and, arising either out of the poorness of the implements, or the lack of root-crops and smallness of the cattle, the co-operative ploughing, and the intermixture of strips in the open fields.

An intelligent class will be interested to notice the different stages in the evolution of private property in land which the list exemplifies.

\section{'What was the eleventh-century map like?'}

This must be worked out on the blackboard, with the. help of the Domesday entry and the modern map. The blackboard diagram should be made in coloured chalks, the class fixing the sites. 
They will naturally start with the river; it is worth while to compare the modern map with the early maps, and to note the drainage that has taken place. The Parish Church and Woodhouse Moor will generally be the next suggestions, while Meadow Lane and Beechgrove Terrace will soon attract attention as names probably indicating the nature of the ground built over, and so furnishing possible clues to the mediaeval geography. 'Mill Hill' is hardly ever noticed without guidance, either because the site is now so far from the river, or because, to the North-country boy or girl, 'Mill' means 'factory'.

When these points have been marked on the map, the houses and open fields should be plotted in co-operatively.

The class should use this diagram as a basis for more detailed individual maps. Even quite mature people will rise to the suggestion that these maps should be 'mediaeval', and should mark the sites by conventionalized drawings instead of by names. It is a good plan to have one holding marked in detail on each map, so that each map shows one set of scattered strips.

When the main outlines of the agricultural system have been grasped and made concrete, it is safe to proceed to more difficult questions of status and origin.

If the subject is to be treated with pupils under $\mathrm{I}_{4}$, the material needs further simplification and the summarizing work should be co-operative.

Where a corner of the class-room or of the garden is available, a model furnishes the best synthesis. If this is impossible, a co-operative diagram can be made with a large sheet of paper and coloured chalks. The class can dictate the scenery, woods, fields, \&c., to the teacher from the reconstructed map. Each child should adopt a villager, and should insert his house, either drawing it on the diagram sheet, or cutting it out from his own piece of paper 
and sticking it in its place. The mill needs special attention, or it will be interpreted as a factory!

The houses involve some conjectural work, as the books on domestic architecture are not very helpful, and contemporary representations generally show palatial mansions. It seems fairly safe to insist on wooden construction, on simplicity of plan, and on lack of convenience; and these give a practicable basis for a child's drawing. Children always ask about the houses, so the subject cannot be entirely ignored.

The needs of the diagram lead to the question of the church. The proximity of Adel makes Norman building a very satisfactory subject to handle in Leeds. It is well to get children early familiar with the characteristic features of Norman work, because the round arch and zig-zag moulding are ubiquitous, and easily recognized; and the pleasure derived from such recognition often leads to an aesthetic appreciation of architecture later on.

[Lessons of this sort raise the whole question of conjectural treatment. The teacher who attacks social or industrial history with children is at once confronted with this problem, and is generally torn in two between the need to be vivid and concrete, and the desire to be scholarly and accurate.

Conjecture, as long as it is carefully made, and resolutely treated as conjecture, seems to me unlikely to do harm, and capable of doing much good. If it is properly handled, it should help to keep the minds of the children open to the difference between conjectured and ascertained facts; it often awakes the desire to investigate for purposes of verification; and it occasionally produces in this way really useful local information.] 


\section{DETAILS OF DRAMATIC WORK}

(i)

\section{Detail of Entertainment given in an Elementary Train. ing College, showing different types of dramatic treatment available.}

\section{Drogramme.}

HISTORICAL VARIETY ENTERTAINMENT.

Given by the First Year History Students,

Dec. 6, 19ז3.

Prehistoric Pantomime, after Kipling . . . . . Div. 4. Stage Manager . . . . . . Miss McLanachan. Property Mistress . . . . . . Miss Wellock. Mesopotamian WAXWORKS . . . . . . . . . . Div. 6. Shown by . . . . . . . . Miss Hornby. Egyptian Legend from Herodotus . . . . . Div. 2.

Original Play by Members of Acland Hall.

Stage Manager . . . . . . . Miss Clough. Greek Skit, from the Clouds . . . $\therefore$. . . . . Div. 6.

New Version by Miss Morton from the Greek of Aristophanes

Chorus of Clouds from . . . . . . . Div. 4.

Cloud March arranged by . . . . . Miss Greenall. Greék Tableaux . . . . . . . . . . Div. 4.

Stage Manager . . . . . . . . Miss HaLL.

Roman SCEne, by W. Shakespeare . . . . . . Div. 2. Stage Manager . . . . . . . Miss Haughton. Armour by Miss Plaisted and the Hand work classes. Beards by Miss BLAKE.

The entertainment arose out of a course of General History taken by the students during their first term. The various 'items' were mainly the work of the students 
themselves. The 'Prehistoric Pantomime' was a dramatized version of 'The Cat That Walked', made by the stage managers. The Egyptian Legend was the best out of a collection of plays based on Herodotus, a subject set instead of a History essay. (It was interesting to notice that the best play sent in was a piece of group work.) The subjects for the Mesopotamian Waxworks, the Greek Tableaux, and the Roman Scene, were chosen by the Divisions concerned in collaboration with the Lecturer.

With the exception of the scene from Aristophanes, the stage management was in the hands of the students : in the Shakespearian scene, they undertook it entirely; in the other.scenes a varying amount of help was given by the Lecturer.

The Mesopotamian Waxworks represented:

(a) Asshurbanipal resting in his garden with his wife.

(b) Nebuchadnezzar exhibiting a model of the Hanging Gardens to the Median Princess.

(c) Cyrus and the Herdsman before Astyages.

Waxworks have two great advantages over the ordinary tableaux : they admit of movement; and the presence of a show-woman allows an explanation of the story and comment on any particular beauties in its presentation. In this case great care was taken to be accurate in such parts of the costume as were specially made for the occasion, e. g. the crown of the Persian king, and the borders of Nebuchadnezzar's robe, which in memory of Nebuchadnezzar's archaic tastes, were copied from a much older wall-sculpture. The Mrs. Jarley of the night was able to call attention to these refinements, and to discriminate between them and the merely suggestive parts of the costume, such as the sofa-cover which draped Astyages.

The Chronicler, who introduced the Greek Tableaux with the relevant portions of Plutarch, was much less effective. The Greek dresses were borrowed, but the armour 
was made by members of the Handwork classes from the illustrations in an archaeological handbook.

The scene from the Clouds (Socrates and Strepsiades) was translated by a member of the Staff, and was rendered more telling by the introduction of topical allusions. The Chorus of Clouds, by moving across the stage and raising their veils, supplied the necessary 'Curtain'.

\section{Treatment of Vocational Interest.}

(a) Pageant based on Folk-lore and Folk-song.

This treatment was suggested by Mrs. Fraser Davies; the material was collected by Miss H. M. Oyler, and the programme was carried out by various schools, private and public, elementary and secondary.

As the woollen industry was the staple trade of the place, nursery rhymes, fairy stories, labour songs, and singing games connected with this, were used. The programme opened with the singing of Blake's 'Lamb' and closed with the 'Lady of Shaiott', included as a literary treatment of an old spinning legend.

Nursery Rhymes. Baa! Baa! Black Sheep.

Bo-Peep.

The Three Mice.

Fairy Tales. . Tom Tit Tot.

Halbetrot.

Folk Songs. Sheep-shearing (Somerset).

Waulking song (Hebridean).

Clapping song (Hebridean).

Singing Game. Wool-weaving Dance (Swedish).

The presentation of the various 'items' was made as dramatic as possible; but the amount of elaboration varied 
greatly ; the Nursery Rhymes were simply 'played' by the babies of the Infant Departments, while the 'Lady of Shalott' was produced as a fully costumed Cantata by the Boys' and Girls' Grammar Schools.

\section{(b) Masque based on Allegorized History.}

This masque was written for the students of an elementary training college and the vocational history allegorized was that of teaching. Incidentally the masque did much to mitigate the rather deadly subject known as "History of Education', and its promoters believed that it ultimately did something to mitigate the rigours of its practice.

The 'Masque of Education' was composed by Miss M. Morton on the model of Ben Jonson's 'Golden Age Restored', from which the structure and many of the words were lifted almost without change. It was called 'What Was and What Will be', and the programme was headed with the quotation 'When Egeria took charge of the school the children were dull, lifeless, listless, resourceless. Now they are bright, intelligent, happy, responsive, overflowing with life, full of ability and resource'. ('What Is and What Might Be', p. 16r.)

Ante-Masque. For Ben Jonson's Iron Age with her attendant Evils--Ambition, Avarice, and the rest--was substituted 'What Was', an old crone with a birch who, on Pallas's promise of 'new life in every school', called up her own peculiar familiars, to resist the innovation.

Come, lead the ranks, thou favourite child,

That Corporal Punishment art styled;

Come bring those instruments of pain,

So well devised to spur the brain, ...

Come to my call, Crass Ignorance,

And come, Servile Obedience;

Bring with thee Fear and Cheating vile,

And Toadying with her falsest smile 
And Parrot Work with long-drawn howl

And Telling Tales with tongue so foul.

Come, Silence, deadly, stiff and mute,

And horrid Cram with bitter fruit.

Now yawning Boredom undisguised,

Come, show how minds are paralysed;

Three R's I worship and revere

I bring thee victims every year.

At the end of this Devil's dance-with its Chorus of

'Spare the rod and spoil the child,

I hate your teacher meek and mild'-

Pallas returns to petrify these Evils of the old régime.

So change and perish, not before your time That 'gainst the children practise such foul crime:

And think to bend unto your will, and mould

Their lives that should like fresh young buds unfold.

Children that should be always free and gay, With joyous dance and merry sound of play,

You make like little statues mute and still,

Clipped to one pattern by your cruel will.

Now in your turn you all are turned to stone

And children free to call their lives their own.

Masque. At the opening of the masque proper, Pallas summons Egeria (instead of Astraea), who calls her goldrobed 'Quire'.

Come, Handwork, blithe and keen and clever,

And come, Free Play, a joy for ever.

Come, Public Spirit, eager, willing,

And Eurhythmics, wonder-filling.

Come, Group-work, with thy busy hum, Break up those rows of children dumb;

Self-government, the Panacea

For rebel hearts unquelled by fear, 
And House-craft, honourable maid, No more a drudge and underpaid.

Come, Fairy Tales and Dramatising.

Come, Open-Air, close rooms despising.

Come, Gardening, Rambles, dance ye all

Round about this noble hall.

Chant ye all our magic spells

Ringing like a peal of bells.

But even thus supported, Egeria, like Astraea, fears

To live agen

With men.

till Pallas calls up, in place of

the far.famed spirits of this happy isle

That Chaucer, Lydgate, Spenser, Gower hight, the great educators.

You far-famed seers of each age and clime,

You seers of Education born before your time,

Come wait upon this Age that shall your name now nourish.

You sowed the seed and now the fields are green and flourish.

The procession begins with Socrates and ends with Dalcroze, till Pallas finally invokes-not the 'Golden Age' of Jonson-but the Spirit of the College where the Masque itself was held, to join the band of educational pioneers.

Ye students all, behold you here,

What Jove hath built to be your sphere

A College to inspire.

And as his bounty gives you cause,

Be ready still without a pause

To show the world your fire. 
She vows against or heat or cold, To spin you garments of her gold,

That ill may touch you never.

She'll lift your thoughts to meet the stars,

You'll march with her in all her wars,

For ever and for ever.

(iii)

\section{Treatment of Local Interest.}

Historical Pageant in town which had little recorded history.

This play arose out of the work of a W. E. A. study circle in a small Yorkshire mill-town. The symbolical treatment was suggested by Mrs. Fraser Davies, who pointed out that the story of the Sleeping Beauty might be regarded as an allegory of the history of the place.

The town had once been famous for its beauty, as it was built on a wooded stream and sheltered by magnificent moorland; but the district had been horribly defaced during the Industrial Revolution, and the modern town consisted of unsightly mills (mainly textile), and mean streets, huddled together in the valley bottom.

The town was personified as the Sleeping Beauty, and the play began with the christening feast of the Princess, at which the Spirits of the Moorland and of the Stream appeared as godmothers.

The site of the town was apparently English, but there were many traces of pre-Teutonic settlement on the Moors around, and this double heredity suggested a procession of the Moorland and Valley peoples as the subjects of Bingheleia's ${ }^{1}$ father.

1 The old form of the town's name. 
The Spirit of the Coal Measures filled the place of the Witch, interrupting the christening festivities to place her curse on Bingheleia, and later, bringing her under the spell with the prick of the spindle.

The knights who attempted the rescue of the Princess were represented by personifications of the various ameliorative influences in the place, Sanitation, Education, and 'Co-op.' (the familiar name of the Co-operative Society, which was extremely vigorous throughout the district, and in this town had started a rather sterile town-planning scheme). These, and even 'W. E. A.' himself, succumbed to the baleful influence of the Spirit of the Coal Measures and her minions.

It appeared to students of the geography of the neighbourhood that the concentration of mills was due mainly to difficulties of transport, and that with the advent of electric-driven machinery, the conglomeration in the valley at this site, as well as the dirt, would disappear. They therefore identified the Victorious Knight as Science, roused to effective action for the rescue of a small child, which had wandered upon the scene, and was in danger of succumbing to the curse of the chimneys.

The Book of Words was mainly anthological; only three sets of verses had to be specially written for the play; the other songs were lifted, with a little adaptation, from Stevenson, Blake, and others. 


\section{BOOK OF WORDS}

[The additions and adaptations made for the play are in italics. Lines in ordinary type have been commandeered without change.]

\section{The Christening Feast.}

Entry of the King and QueEn with the infant Bingheleia, followed by a procession of the PEOPLE OF THE Moor and the People of the Valley.

They sing--

[to the tune of a North-country sword-dance.]

PEOPLE OF THE Moor-

We dwell on the moor 'mid the heather,

The purple's the badge of our race,

We are old as the wind and the weather,

We kings of the wide open space.

People of The VAlley-

Oh, green is the place of our dwelling!

Oh, happy the scene of our. birth!

We are lords of a land that is swelling.

With all the good gifts of the earth.

PEOPle of THE MoOR-

We are clean with the rains that come storming,

We are swept with the winds of the air:

The sun in his might is our warming;

We are free on the moorland bare.

People of The VAlley-

How dear is the time of the fiow'ring,

The budding in woodland and plain!

How glad is the time of the dow'ring

Of fields with their golden grain! 
People of The Moor-

$O$ hark to the cry of the curlew Thro' silences mournfully borne!

$O$ watch how the deredrop will pearl you The bells of heather at dawn.

People of the Valley-

But hark to the song of the throstle,

The lark soaring high o'er the corn; In the valley the birds throng and jostle

To wake you with songs in the morn.

People of THE MOOR-

The flints on the moor are our arrows;

By the rocks on the hill-tops we pray;

On the breast of the moor, see the barrows

Where we rest at the end of our day.

\section{People of the Valley--}

With seed-time and harvest and tillage

Aire valley shall laugh and shall sing;

By the ford of the river our village

Shall gather us under her wing.

The Spirit of the Stream enters.

I come from haunts of coot and hern, I make a sudden sally,

And sparkle out among the fern,

To bicker down the valley.

I chatter over stony ways, In little sharps and trebles,

I bubble into eddying bays,

I babble on the pebbles. 
I slip, I slide, I gloom, I glance, Among my skimming swallows;

I make the netted sunbeams dance Against my sandy shallows.

And thus by Bingley's ford I flow

To join the brimming river,

For men may come and men may go,

But I go on for ever.

-Adapted from Tennyson, The Brook.

The Moori.and Spirit enters.

Down from the lonely moorland,

Where the plovers are wheeling and crying,

Beneath the wide spaces of sky, where

The storm-driven clouds are flying;

From miles of heath and bracken,

From the land of rain and hail,

From the wild, pure airs of the uplands,

I come to the child of the dale.

The Spirit of the Stream blesses Bingheleia.

Grow, O Maiden, free and fair,

Pure and blithe and debonair;

Rising from the waters fleet

She shall set her milk-white feet

O'er the cowslip's velvet head

That bends not beneath her tread:

Often walking, young, serene,

By hedgerow elms and hillocks green,

Russet lawns, and fallows grey

Where the nibbling flocks do stray,

Thro' meadows trim with daisies pied, By babbling brooks and woodlands wide, 
To hear the lark begin his flight And, singing, startle the dull night; And the cock, with lively din, Scatter the rear of darkness thin : While the ploughman near at hand

Whistles o'er the furrowed land, And the milk-maid singeth blithe, And the mower whets his scythe. Flozers shall blow about her knees: Thrushes' song and hum of bees Shail be with her through the hours In her green and shady bowers.

-Adapted from Milton, Comus and L'Allegro.

The Moorland Spirit blesses Bingheleia.

Grow, O Maiden, fair and free, Blessed by space and liberty.

From the ragged moor receive The incomparable pomp of eve, And when the wind from place to place Doth the unmoored cloud-galleons chase, Shall your gardens gleam again With leaping sun, with glancing rain. Here shall the wizard moon ascend The heavens, in the crimson end Of day's declining splendour; here The army of the stars appear. The neighbour hollows, dry or wet, Spring shall with tender flowers beset:

When daisies go, shall winter-time Silver the simple grass with rime; Autumnal frosts enchant the pool, And make the cart-ruts beautiful; And when snow-bright the moor expands, How shall your children clap their hands!

-From Stevenson, The House Beautiful. 


\section{R A M A T I C W O R K}

[All dance and lull the Baby.]

$$
\text { The Lullaby. }
$$

The linnet in the rocky dells,

The moor-lark in the air,

The bee among the heather bells,

Shall lull our baby fair.

Blow, West Wind, by the lonely mound,

And murmur, summer streams;

There is no need of other sound

To soothe our baby's dreams.

-Adapted from E. Brontë, My Lady's Grave.

The Spirit of the Coal Measures breaks in upon the dance.

Song of the Spirit of the Coal Measures.

Ha! Ha! The Black Witch has come with the rest; Tho' I' $m$ lame as a gull, by His Highness possessed, I can shoulder my crutch and dance with the best.

Sporting and snorting in shades of the night, Their ears pricking up and their hooves striking light, My imps are working the coal so bright.

Footing and flaunting it all the night, Each lock flings fire and each pick strikes light ; No lamp need they whose breath is bright.

$I$ beckon the moon and the moon comes down, The green earth shrivels beneath my frown, Neither moorland nor meadow can keep their own. And so the Black Witch has come with the rest Though she's lame as a gull by His Highness possessed, She'll shoulder her crutch, and dance with the best.

-Adapted from Juba's Song in Callista.

(Cardinal Newman.) 
The Spirit of the Coal Measures curses Bingheleia. Grow, $O$ Maiden, grim and old, Dowered with smoke and grime and gold.

Through thy meadows, foully black,

By asphalt path and cinder track,

Thy polluted feet shall stray,

Knowing neither night nor day.

And, for thy defiled ways,

Take wealth and power and length of days;

And the doom that follows quick

Ever on the spindle's prick.

\section{The Spell.}

The Spirit of the Coal Measures is discovered disguised as an old woman spinning.

Enter Bingheleia, with the Siririts of the Stream and of THE Moorland dancing. At the sight of the oldlwoman, BINGHELEIA advances to the spinning-wheel, pricks her finger, and is immediately surrounded by a band of black imps (led by the GoldEn DWARF) who bind Bingheleia, and set about her a girdle of Chimneys, while the witch lays her and her attendant Spirits under a spell.

\section{The Incantation.}

Dank and foul, dank and foul $B e$ the smoky town in its murky cowl. Foul and dank, foul and dank With wharf. and sewer and slimy bank. Darker and darker and meaner it shows, Baser and baser, the richer it grows. Who can live with thee, sin-defiled? Pine in thee, die in thee, mother and child. Dirt and grime, dirt and grime Breeding and fostering drink and crime. 
Sweat and toil, sweat and toil

With none to save from the fatal coil.

Faster and faster the wheels whirl around,

Louder and louder the harsh roaring sound.

Mother and child and the babe in the womb,

All in the merciless Mill find their doom.

Moor and Vale, Moor and Vale,

Over them all the hideous trail.

Fog and smoke, fog and smoke

Belching out, a horrible cloak.

Blacker and blacker the spell as I weave

Scarcely the tops of the hills will I leave.

Wait till I hide the sun from thy sight,

Wait till I curtain the stars at night.

Adapted from C. Kingsley.

\section{The Attack of the Knights.}

Enter M. O. H., attacking the barrier.

The Golden Dwarf (bewitching him)-

I rose up at the dawn of day;

Get thee away: get thee away.

Pray'st thou for riches? Away, away!

This is the throne of Mammon grey.

Enter Education-

I will not cease from mental fight,

Nor shall my sword sleep in my hand,

Till we have built Jerusalem

In England's green and pleasant land.

[Attacks, but gets into difficulties with his equipment and falls to tying his boot-laces made of red-tape.]

The Witch-

Great things are done when men and mountains meet; These are not done by jostling in the street. . 
Co-or, attacks-

The Dwarf (bewitching him)-

When nations grow old the Arts grow cold,

And Commerce settles on every tree,

And the poor and the old can live upon gold,

For all are born poor, aged sixty-three.

W.E.A. (in an idealistic attitude)-

And did the Countenance divire

Shine forth upon our clouded hills?

And was Jerusalem builded here

Among these dark Satanic Mills?

Bring me my bow of burning gold!

Bring me my arrows of desire!

Bring me my spear! O clouds unfold,

Bring me a chariot of fire.

ThE IMPS-

[attacks the barrier.]

Get thee away! Get thee away!

This is the throne of Mammon grey.

[The KNights are now all spell-bound in various attitudes.]

The Spirit of the Past laments over the scene.

I wander through each sordid street,

Near where the blackened Aire does flow,

And mark in every face I meet

Marks of weakness, marks of woe.

In every cry of every man,

In every infant's cry of fear,

In every voice, in every ban,

The mind-forg'd manacles I hear.

From Blake. 


\section{The Awakening.}

[The verses in this scene are from various poems of Blake, and from Kipling's The Recall.]

Enter The Spirit of the Future.

The Spirit of the Future-

A robin red-breast in a cage

Puts all heaven in a rage.

A sky-lark wounded on the wing,

Doth make a cherub cease to sing.

$\mathrm{He}$ who shall hurt the little wren

Shall never be beloved by men.

Joy and woe are woven fine,

A clothing for the soul divine.

Under every grief and pine

Runs a joy with silken twine.

It is right it should be so;

Man was made for joy and woe.

And when this we rightly know,

Thro' the world we safely go.

The babe is more than swaddling-bands:

Throughout all these human lands.

Tools were made, and born were hands;

Every farmer understands.

[The Spirit blows her trumpet, and the Knights stir.]

The Imps' Spell-

Get thee away! Get thee away!

This is the throne of Mammon grey.

The Spirit of the Future-

Every tear from every eye

Becomes a babe in Eternity.

He who mocks the infant's faith

Shall be mocked in age and death. 
If the sun and moon should doubt They'd immediately go out.

The ImPS-

[She blows her trumpet again.]

Get thee away! Get thee away!

The Spirit of the Future-

God appears and God is light

To those poor souls who dwell in Night;

But does a human form display

To those who dwell in realms of day.

[She blows her trumpet a third time. A very small child appears, attracted by the noise, and approaches the barrier. Seeing the child in danger, the KNights are thoroughly roused and renew the attack. Meanwhile in the rear a NEw KNIGHT appears, and approaches The Spirit of the Conl Measures.]

The New Knight-

Spirit! Spirit! burning bright

In the forges of the night;

What immortal hand or eye

Could frame thy fearful symmetry?

The Coal Spirit-

In what distant deeps or skies?

Burnt the fire of thine eyes?

On what wings dare he aspire?

What the hand dare seize thy fire?

The New Knight-

When the stars threw down their spears

And watered heaven with their tears,

Did he smile his work to see?

Did He who made the lamb make thee?

[As the Coal Spirit draws back, the Yellow Dwarf 
begins to unweave the black spells, and the KING and QueEn return to the scene.]

The QueEN-

I am the land of their fathers,

In me the virtue stays;

I will bring back my children

After certain days.

The Moorland Spirit (standing free)-

Under their feet in the heather

My clinging magic runs;

Though they return as strangers,

They shall remain as sons.

The Stream Spirit (rising)-

Over their heads, in the branches

Of their new-bought ancient trees,

I weave an incantation,

And draw them to my knees.

The KInG-

Scent of smoke in the evening,

The QUEeN-

Smell of rain in the night,

Past and Future-

The Hours, the Days, and the Seasons,

All Four-

Order their souls aright;

PASt and Future-

Till I make plain the meaning

Of all my thousand years.

Science-

Till I fill their hearts with Knowledge, 
Stream and Moor-

While we fill their eyes with tears.

[The Knights have by this time cleared a path for the child. As it reaches Bingheleia, she rises to meet it.]

Bingheleia-

I am the home of their fathers, In me the virtue stays.

I will bring back my children After certain days. 



\section{BOOKS ON EDUCATION \\ May 1920}

THE UNIVERSITIES AND THE TRAINING OF TEACHERS. A Lecture delivered in the Hall of Queen's College on October 22, 1919 , by F. J. R. Hendy. 1920. 8vo $\left(9 \frac{1}{4} \times 6\right)$, pp. 28. Paper cover, 1s. 6d. net.

EDUCATIONAL REFORM. Speeches by the Right Hon. H. A. L. Fisher. With a summary of the Education Bill of 1918 . 8 vo $(9 \times 6)$, pp. xvi +102 . Is. net.

\section{EDUCATION TO-DAY AND TO-MORROW. Addresses}

by P. E. Matheson. 1917. 8vo $(9 \times 6)$, pp. 140. 2s. 6d. net.

' Few current edncational writings have such a deep spring of idealism and interest in their relation to daily school life as these addresses. They represent the best thought on education that was available immediately before the war, and are of peculiar interest as showing the real forces that lay behind the reform movement.'-Times (Educational Supplement).

AN ADDRESS to the Swindon Branch of the W. E. A., by R. liRIDGes. 1916. Fcap 8 vo $(7 \times 5)$, pp. 38. 2s. net. Paper cover, Is. net.

EDUCATIONAL SYSTEMS of Great Britain and Ireland, by Sir Graham Balfour. Second edition, 1903. $8 v 0\left(8 \frac{3}{4} \times 5 \frac{3}{4}\right)$, pp. xxxiii + 308. 7s. 6d. net.

'We know of no book in which the history and actual position of education in the three departments-elementary, secondary, and higher-as they have been developed and exist in the Inited Kingdom, are so clearly and accurately set forth.'-Manchester Guardian.

SECONDARY EDUCATION IN SCOTLAND. A History from Early Times to the Act of 1908 , by John Strong. 1909. 8vo $\left(8 \frac{3}{4} \times 5 \frac{3}{4}\right)$, pp. viii +288.7 s. 6d. net.

'No work has yet been written in which within convenient compass the educational history of our own times has been set forth with such clearness.'

Dundee Courier.

EDUCATIONAL VALUES AND METHODS based on the Principles of the Training Process, by W. G. Sleight. 1915. Crown 8 vo $\left(7 \frac{3}{4} \times 5 \frac{1}{4}\right)$, pp. viii $+364 \cdot 5$ s. net.

'Dr. Sleight reveals himself in this book as one of the most careful and methodical of our thinkers on education. We have found his book clearheaded and suggestive beyond most works on education and full of that quality of argumentative forcefulness which compels the reader to examine the foundation of his own opinions.'- Journal of Education.

THE EARLY EDUCATION OF CHILDREN, by LaURa L. Plaisted. With a chapter on the Medical Responsibilities of School Teachers, by A. L. Ormerod. Second edition. Fourth impression. 1918. Crown $8 v o\left(7 \frac{1}{2} \times 5_{4}^{\frac{1}{4}}\right)$, pp. xiv +398 , with twelve plates and thirty-two illustrations in the text. $6 \mathrm{~s}$. net.

'A more helpful guide to all engaged in the education of children could not be desired.... Every method recommended has stood the test of practical work.'-Aberdeen Daily Journal. 
HANDWORK and its Place in Early Education, by Laura L. Plaisted. 1913. Crown 8 vo $\left(7 \frac{1}{2} \times 5 \frac{1}{4}\right)$, pp. $x i v+328$, with two hundred illastrations. 5s. net.

'An interesting volume with many helpful suggestions.'-Times.

HANDWORK AND SOCIAL HISTORY. Scenes from early and mediaeval history to be reproduced by children. By E. STEvinson. 1916. Crown 8 vo $\left(7 \frac{1}{2} \times 5 \frac{l}{4}\right)$, pp. I 12 , with ninety-five illnstrations. 3s. net. Contents :-The Stone Men; Men of the Bronze Period; The Early Saxon Period; A Norman Castle ; Life in a Mediaeval Town, Village, Manor House; Mouasteries and Schools in Mediaeval Days; Travelling in the Middle Ages.

- A pleasantly illustrated handbook.... Certainly this should be an attractive way of learning social history for children of eight or nine.' - Times.

THE RUDIMENTS OF CRITICISM, by E. A. GREENING LAMBORN. Crown 8vo, pp. 192, with a supplement of children's verses and essays, and selected questions. 35. 6d. net.

'A valuable book for teachers, showing how children may be tanght to appreciate poetry and verbal melody. If the views expounded were taken to heart by teachers there might be fewer superfluous poets in the next generation, but an enormously larger body of intelligent readers of poetry....'-Athenaeum.

LANGUAGE TEACHING: Theory and Practice, with special reference to French and German, by E. C. Kitson. I918. Crown 8 ro $\left(7 \frac{1}{2} \times 5 \frac{1}{4}\right)$, pp. $x i v+186$. 4 s. net.

- A carefully-rcasoned study of the principles which underlie language and of the best methods of applying such principles in the teaching of modern language. ... . The book contains much useful information, is always suggestive and original, and should be on the bookshelf of every teacher of modern languages.'-Scottish Educational Journal.

\section{THE TEACHING OF HISTORY, by E. H. JARVIS.} 1918. Crown 8 vo $\left(7 \frac{1}{2} \times 5 \frac{1}{4}\right)$, pp. 240. 4s. 6d. net.

'The subject is one of the first importance and is here dealt with in detail.'

The book as a wbole deserves the careful consideration of teachers. It is illuminating and helpful.'-School World.

LESSONS IN ENGLISH HISTORY, by H.W. CARTER. 1917. Pp. 208, with sixty-seven maps, plans, and illustrations, bibliography, extracts from contemporary writers and ch ronological chart. 3s. 6d. net.

Sixty-eight outlines upon which the teacher can construct lessons for a two years' course for middle forms, or, by selections, a year's course for junior forms.

A STUDY OF MATHEMATICAL EDUCATION including the Teaching of Arithmetic, by BENCHARA BRANFORD. Igos. Crown 8vo $\left(7 \frac{1}{2} \times 5\right)$, pp. $x i i+392$. 5s. net.

' The book is certainly one which will well repay study, for it contains much that is sresh and interesting, and it stresses many vital but neglected points in teaching.'-Journal of Education.

THE PREPARATION OF THE CHILD FOR SCIENCE, by M. E. Bool.E. 1904. Crown 8ro $\left(7 \frac{1}{2} \times 5\right)$, pp. 158 . 2s. 6d. net. 


\section{BY F. S. MARVIN}

THE LIVING PAST, a Sketch of Western Progress. F. S. MarviN. Fourth edition, 1920. 6s. 6d. net.

CONTENTS:-Looking backward. Childhond of the Rame Enrin Fmpires. The Greeks (roo A n :

Renascence.

Revoli

Appen +3 :

'An ज.:

special

this wo

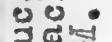

wit

THE

gress $\mathrm{A}$

Crown

Conth

New $S$

Inventi

for Al

Expan:

Appen 0

'Mr. $\mathrm{L}$

excepti

tempos

a pows

consist

THE

collecte

Ground

Contrib

E. BAR

sophy,

Finance

Reform

H. G.

PRO

MARV1.

The Id

MARET

Middle

HUEGE

ZimMe:

Progres:

REC]

THOU

pp. 306

litical

Charts.

University of Toronto

Library

cessive

tive in

ient.'

slletin.

Pro-

I920.

DO NOT

REMOVE

THE

CARD

FROM

THIS

POCKET

'ssays

UYRES.

e Ages,

Philo-

ce and

Social

sligion,

․ S.

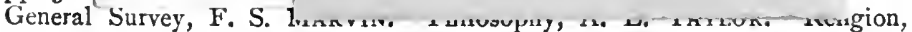

F. B. Jevons. Poetry, C. H. Herford. History, G. P. Gooch. Political

Theory, A. D. LindSAY. Economic Development, C. R. FAY. Atomic

Theories, W. H. Bragg. Biology since Darwin, Leonard Doncaster.

Art, A. Clutton-Brock. A Generation of Music, ErNest Walker. The

Modern Renaissance, F. Merjan Stawelt. 


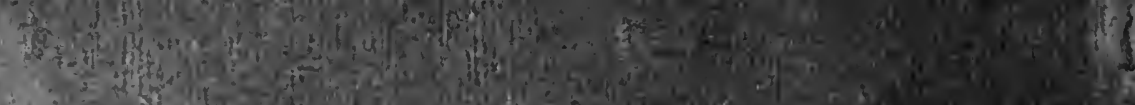

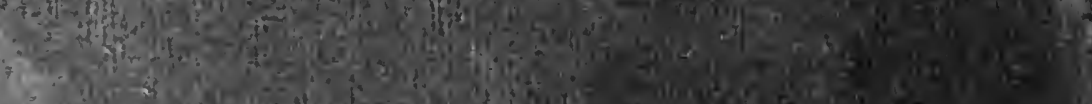

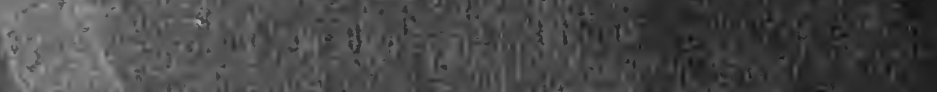

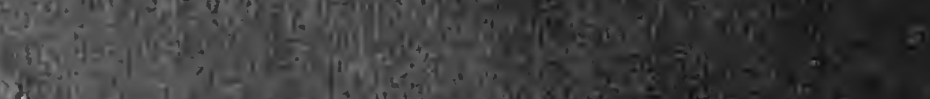

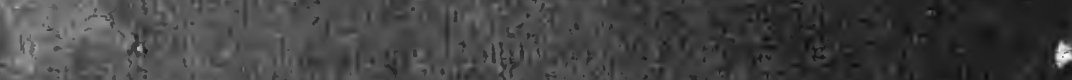

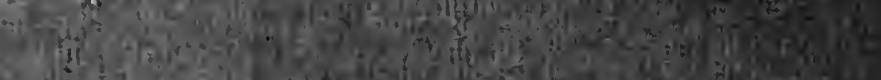

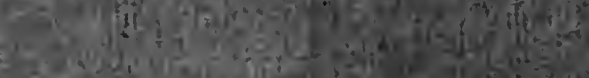
Whathes $+4$ 50 (2)

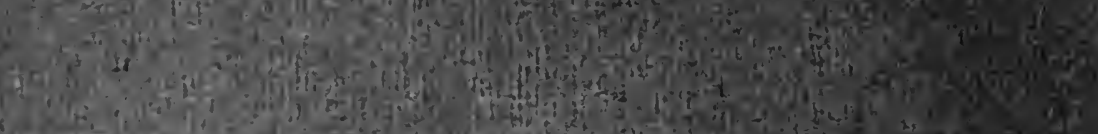

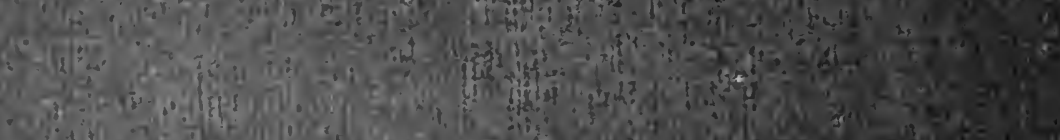

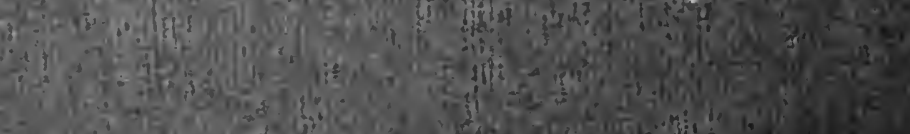
Bar

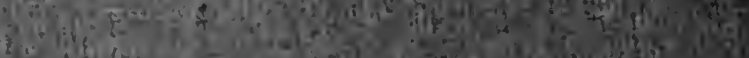
and

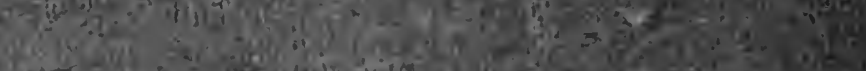
Hat

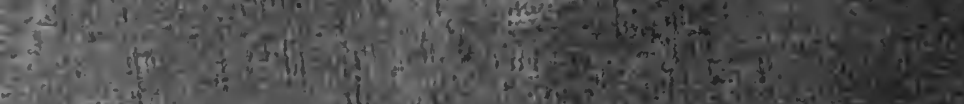

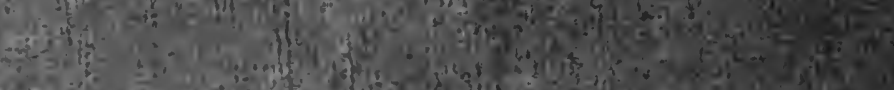

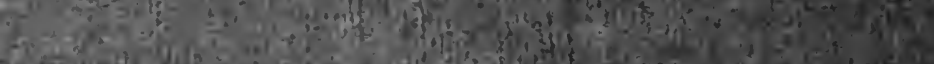

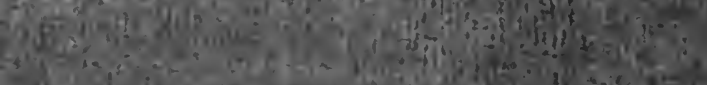

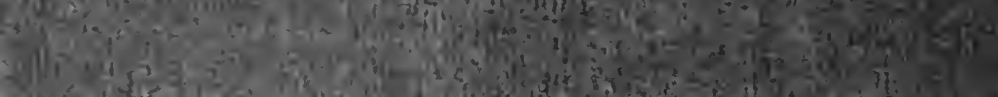

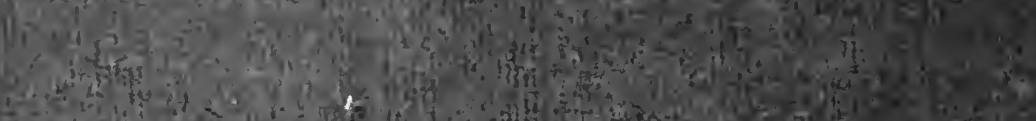
24.

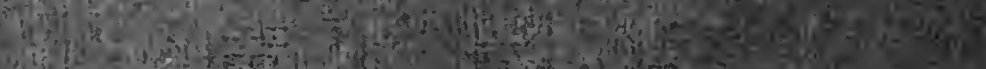
8 